\title{
END OF HISTORY, COVID 19, AND NEW LEVIATHAN THE BROKEN COMMUNICATION BETWEEN MODERNISM AND POSTMODERNISM
}

\author{
Emil Vlajki \\ Faculty of Political Sciences, University of Banja Luka, Bosnia and Herzegovina
}

\begin{abstract}
This work is about the spirit of Western civilization and its temptations. Drawing on Hegel's philosophy of history, the text explains why, until recently, this civilization was dominant over the rest of the world. The thing is that she understood the importance of rationality, subordinated all manifestations of life to her and especially, during capitalism (modernism), developed science and technology, and produced powerful weapons. Along the way, she incorporated all the significant achievements of other civilizations and peoples into her system of rationality. In this regard, Hegel says in the introduction to the Philosophy of History: „The only Thought which Philosophy brings with it to the contemplation of History, is the simple conception of Reason; that Reason is the Sovereign of the World; that the history of the world, therefore, presents us with a rational process." In other words, history is exclusively occupied with showing how Reason (Mind) comes to a recognition and adoption of the Truth. Of course, rationality is something that belongs to all civilizations and peoples, but other societies, for various reasons (geographical, climatic, religious, etc.) subordinated rationality to some other imperatives. Therefore, many of these communities were non-historical. Whatever it was, the West exploited its supremacy by colonizing other civilizations and destroying some. From the usual moral point of view, it is unacceptable, criminal. However, Hegel's philosophy, somewhat in Marx and Engels's interpretation, says something else. History makes sense. Its primary goal is to preserve humankind from anything that could destroy it, especially from various natural cataclysms and deadly diseases. The meaning of history is also its progress towards civil society as the realization of freedom and the end of history. This was only possible by adopting and practicing absolute rationality. Why guns and violence? Absolute rationality, in order to be historically efficient, had to cover the whole world. In the West, as a "chosen civilization", it was to make it happen and he, militarily superior, did so by submiting other civilizations and nations to the extreme violence. On the other hand, with this relentless exploitation of colonized areas, the West was able to develop rapidly in every way and thus, at the level of possibility, achieve the best destiny of humankind. Especially important was the XX century. Then this civilization, developing medicine, genetics, computer science, nanotechnology and robotics, managed to defeat various deadly diseases, begin space exploration, and turn deserts into fertile soils and, with the "green revolution", produce food for all the inhabitants of the planet. Seeing the advantages of rationality, other areas of the world, with varying success, followed the example of the West. Colonialism disappeared, and human rights and international relations were institutionalized, especially throughout the United Nations. The détente between the two blocs, capitalism and socialism, was established, and the non-aligned movement contributed to the stabilization
\end{abstract}


of the world. As for the world's environmental problems arising from the often-uncontrolled industrialization, they too, although excruciating and slow, seek to be solved on a global scale. Unlike modernism, which was constituted as a modern civil society with the adopted principle of equality of all, the current postmodernism is the opposite of everything civil. The market economy is functioning less and less, major utopian ideas, Christianity and Marxism, have been abandoned, the "new human rights" destroyed everything noble of the already proclaimed universal human rights. In the resulting hopeless chaos, worried about the rise of China and Russia, the most important forces in the West crossed in the "illegal" making a global deep state, the New Leviathan. They operate, as needed, both through formal and informal mechanisms. If necessary, they also oppose the authorities of their states if they deem their actions to be collapsing this civilization. As good disciples of Carl Schmitt, the German political philosopher, they are against the humanization of interpersonal relations; they have enormous financial and technical means and inhuman, eugenic ideas about reducing the world's population. There is no longer any doubt that their methods include the production and dissemination of deadly viruses. The action of these anti-liberal shadow minds is the destruction of all existing humanism, and has nothing to do with history or any sense.

Note. Leviathan is a sea monster mentioned in the biblical Book of Job, where it is associated with the forces of chaos and evil. Metaphorically, Leviathan is a huge and powerful social organism living secretly in the darck deep, out of any legal social control.

The work has two parts:

- The Sense of History, Modernism and the Necessity of Western Violence

- Postmodernism, the twilight of the West and the New Leviathan

The following is a conclusion about the future of humanity.

Keywords

Hegel, history, dialectics, rationality, communication, modernism and postmodernism, West, western violence, civil society, global deep state, capitalism, Carl Schmitt, eugenics, Kovid 19, vaccine, extreme world right, international relations, pathology of Mind, new world order, "big reset".

\section{PROLOGUE}

\section{Carlo Maria Viganò}

Libera Nos a Malo (Free Us From Evil)

Considerations on the Great Reset and the New World Order

31 Agosto 2021

For more than a year and a half we have been helplessly witnessing the succession of incongruent events to which most of us are unable to give a plausible justification. The pandemic emergency has made particularly evident the contradictions and illogicalities of measures nominally intended to limit contagion lockdowns, curfews, closures of commercial activities, limitations of public services and classes, suspension of citizens' rights - but which are disavowed daily by conflicting voices, by clear evidence of ineffectiveness, by contradictions on the part of the same health authorities. There is no need to list the measures that almost all the governments of the world have taken. If we limit ourselves to the presumed advantages that the experimental gene serum should have brought to the community, we discover that an Oxford University study published in The Lancet stated that the viral load of those vaccinated with a double dose is 251 times greater than the first strains of the virus. In the other side, the Italian Prime Minister 
Mario Draghi said: "whoever gets vaccinated lives, whoever does not get the vaccine dies."

The art of medicine, seems to have renounced its prudence, in the name of an emergency that has risen to the level of priesthood of a religion. The ministers of this cult have constituted themselves as a caste of untouchables, exempt from any criticism. And just as there are new Covid priests, so there are also new heretics, that is, those who reject the new pandemic religion and want to remain faithful to the Hippocratic Oath. The aura of infallibility that surrounds virologists and other titled scientists does not seem to be questioned due to their conflicts of interest or by the substantial financial benefits received by pharmaceutical companies, which under normal conditions would be scandalous and criminal.

If in Sweden the absence of lockdowns and masks did not lead to higher infection rates than those in countries where people have been confined to their homes or where they have had masks put on even in primary schools, this element is not considered as proof of ineffectiveness of the measures. If in Israel or in Great Britain mass vaccination has increased infections, their example does not induce the rulers of other countries to be cautious in the vaccination campaign. If ivermectin or hyperimmune plasma prove to be valid treatments, this is not enough to authorize them. And those who wonder the reason for this disconcerting irrationality end up refraining from judgment.

We are faced with a deception, based on lies and fraud. The mistake consists in believing that the rulers are honest and that they do not lie to us. So we persist in finding plausible justifications and to close our eyes to reality and to believe the most shameless lies.

What the Rothschilds, the Rockefellers, Klaus Schwab, and Bill Gates have been saying since World War II has been taken up by international bodies and foundations, made up by parties and government majorities.

Once it is understood that the present events have been intended in order to obtain certain results, we must also have the honesty to recognize the criminal mens [mind] of the authors of this plan. This criminal design also makes us understand the fraud perpetrated by civil authority in presenting certain measures as an unavoidable response to unpredictable events, when the events have been artfully created and magnified with the sole purpose of legitimizing a revolution - which Schwab identifies as the fourth industrial revolution - intended by the elite to the detriment of all humanit. The enslavement of authority is a result of the economic and financial potentates, of the international oligarchy of bankers and usurers, of multinationals and pharmaceutical companies.

Equal enslavement is also evident in the media: journalists have accepted, prostituting themselves to the powerful, going so far as to censor the truth and spread shameless lies without even trying to give them the appearance of credibility. Up until last year journalists counted the numbers of the "victims" of Covid by presenting anyone who tested positive as terminally ill; today those who die after being vaccinated are always and only taken by a vague "illness," and even before the post mortem examinations they officially decide that there is no correlation between a person's death and the administration of the gene serum.

What has been happening for a year and a half had been widely announced, down to the smallest detail, by the creators of the Great Reset themselves. On February 17, 1950, testifying before the United States Senate, the well-known banker James Warburg said, "We will have a world government, whether you like it or not. The only question that arises is whether this world government will be established by consensus or by force." Four years later, the Bilderberg Group was born. In 1991, David Rockefeller wrote: "The world is ready for a world government. The supranational sovereignty of an intellectual elite and world bankers is certainly preferable to the national self-determination practiced in past centuries." And he added: "We are on the verge of a global transformation. All we need is the 'right' global crisis and the nations will accept the New World Order." Today we can affirm that this "right crisis" coincides with the pandemic emergency and with the "lockstep" outlined since 2010 by the Rockefeller Foundation document "Scenarios for the 
Future of Technology and International Development," in which the events we are now witnessing are all anticipated.

In short, they have created a false problem in order to be able to impose population control measures as an apparent solution, cancel small and medium-sized businesses with lockdowns and the green pass to the benefit of a few international groups, demolish education by imposing distance learning, lower the cost of manpower and employees with "smart working," privatize public health for the benefit of BigPharma, and allow governments to use the state of emergency to legislate in derogation of the law. There is not a single magistrate who opens a file against them to ascertain the truth and condemn the guilty and complicit. Those who disagree are not only censored but pointed out as public enemies.

Now, in the face of a criminal plan it would be at least logical to denounce it and make it known, in order to then be able to avert it and try those who are guilty. The list of traitors should start with the heads of government, with cabinet members and elected officials, and then continue with the virologists and corrupt doctors, the complicit officials, the leaders of the armed forces incapable of opposing the violation of the Constitution, the sold-out journalists, the cowardly judges and the obsequious unions.

In June 2011 the Sovereign Independent carried the headline on its front page: "Depopulation Through Forced Vaccination: The Zero Carbon Solution!". Beside the headline, a photograph of Bill Gates was accompanied by a quote from him: "The world today has 6.8 billion people. That's headed up to about 9 billion. Now if we do a really great job on new vaccines, health care, reproductive services [abortion and contraception], we lower that by perhaps 10 or 15 percent." Today he is one that finances the pharmaceutical companies that produce the vaccines, one of the main sponsors of the World Health Organization (WHO). At his side we curiously find George Soros, the "philanthropist" of the Open Society, which together with the Bill and Melinda Gates Foundation recently invested in a British company that produces swabs for Covid testing.
Holy See's declarations that the genetic serum represents a "moral duty" for every Christian; the introduction of the "Green Pass"health passport in the Vatican and in Catholic schools; the Holy See prohibiting Bishops from announcing that they are against the vaccination obligation - these are all elements that demonstrate the subordination of the deep church to the orders of the deep state. If we combine all this with the declaration that the death penalty is morally illicit; the words of understanding for LGBT issues, homosexuals, and transsexuals; the silence over the legitimization of homosexual unions and the even more disconcerting silence over the blessing of sodomitical couples by German Bishops, we realize that is meant to constitute the Universal Religion in support of the New Order.

In the course of history, totalitarian regimes have been overthrown by force. It is difficult to think that the health dictatorship can be fought differently, since all the powers of the State, all of the means of information, all the international public and private institutions, all of the economic and financial potentates are complicit in this crime. Where authority fails in its duties and betrays the purpose for which it has been established, disobedience is not only lawful but obligatory.

(Carlo Maria Viganò is an archbishop of the Catholic Church who served as the Apostolic Nuncio to the United States from 19 October 2011 to 12 April 2016.)

\section{PART ONE}

The Sense of History, Modernism and the Necessity of Western Violence

The degree of rationality determines the historicity and power of a civilization, people or state. /1/ It was the West, especially its Protestant part (Weber) that understood this certainty most fully. This orientation of the West towards absolute rationality to which everything else is subordinate, has allowed him to rule over much of the world. This imperialist period achieved during the Roman Empire, was restored at the beginning of liberal capitalism, declined in the era of decolonization, reached its peak with the creation of the "states of 
prosperity" of the twentieth century and, in the broadest sense of the word, is known as modernism.

\section{Supremacy of the West}

Modern practice has shown that dominance on a global scale includes, in addition to developed science, technology and constantly perfected weapons, the will for power, strong central government, social Darwinist conception of society, aggressive militaristic spirit, large territory and a large population. In this sense, those who are, currently, on a planetary level have distinguished themselves are U.S., Russia and China. Although by the middle of the XX century they were superpowers, Germany, France and England, after decolonization, no longer meet all the necessary criteria.

Conglomerates of independent states, such as the European Union, due to mutually opposing interests and constant friction, are incapable of truly participating in the rule of the world; The European Union is now practically a vassal of the United States both economically and through NATO.

Islamic societies, where irrational in the image of Allah is above rationality, and what follows the greatest number of believers, are forced to always lag behind the West. /2/

Admittedly, hyper-rational societies (primarily the U.S. and their Western vassals) are also constantly invoking God but this looks more like political marketing through which they justify their expansionism. It is only China that omits religion in its attempts to dominate the world using earthly soft methods. /3/

The rulers of the world do not have an ideology in the classical sense of the word. Their aspiration is to preserve themselves, constantly strengthen and impose themselves on others. Each of them has its own interest zones. In this way, they determine the essence of international relations, the dynamics of which depend on the continuous struggle to expand their influences.

The West, until recently, has achieved world domination in many ways. First, through market relations. This is one of the "cunnings of the Mind"/4/, within which, given their enormous advantage (scientifically-technologically, financially), they extract huge profits. Likewise, they put many countries in debt bondage, and because of their over-indebtedness, they receive free, in the name of debt, their products, in particular raw materials. Then, in their interest spheres, they establish puppet governments. Where they can, forcibly overthrow the authorities of individual countries, provoke conflicts on national and religious grounds, and intervene (para)militarily while inventing various false justifications for their militaristic actions.

In order to facilitate the rule of the planet, Western rulers have imposed on less rational societies some moral and political values that they claim are universal: natural law, individualism, parliamentary democracy and (new) human rights. These are the modes of action of the "cunning Mind" which allows, along with other neocolonial mechanisms, to keep other societies, especially developing countries, dominated and exploited.

Indeed, it is clear that poor countries must have centralized power in order to develop economically. This was shown by the example of South Korea, Iraq, Libya, Romania and Yugoslavia. The West, except South Korea, destroyed the other four countries, giving a clear, threatening message to other societies that would try to pursue an independent policy of development. /5/ Most broadly, it is obvious that in the development phase of an underdeveloped country, parliamentary democracy (many parties, many conceptions, and many rifts) is detrimental to any progress.

\section{The people support imperial expansion}

Let us also mention that the inhabitants of the countries that dominate the world know that their relatively pleasant existence depends on the imperial action of their authorities and this fact is more important to them than both God and universal moral principles. For example, says Claude Julien in his book L'empire americain, USA with $4 \%$ of the world's population, spends over thirty percent of what is produced in the world! Who would give that up? Such populations are just as imperialist as their authorities are. For example, when 
the U.S. wages some of its frequent neocolonial wars, its presidents' ratings go up to forty percent!

It is no random fact that in mass-screened natural science TV shows of the "survival" type, powerful predators attack, slaughter and eat, while still alive, their far weaker victims, say antelopes or zebras that are lovely, peaceful and eat grass. This is scientifically called the "food chain" in social-Darwinian jargon. It serves as an existential-moral pattern for entire generations of young, human predators who, when they grow up, will also become hyenas, wolves, lions, eagles and similar animals and birds.

The upbringing of these generations is also completed with predatory, warrior video games whose basic content is a fight to the death where the most important thing is to kill a virtual enemy cruelly and without any pity. Political video games are especially made for youth, indoctrinating it with the official attitudes of the West towards the rest of the world. /6/

Young people, of course, through childhood, are taught the classical morality of the Moses type and empathy ("don't kill," as it sounds ridiculous). However, when they come to life, primarily those who are destined to be the ruling elites, are truly prepared to act completely in cold blood, business ruthlessly and ready for violence against the weak.

The ruling class is an authentic representative of absolute rationality. Emotions, imagination, irrational behaviors, etc., can only be freely manifested if they do not harm scientifically based rational ways of conducting all life.

It means that emotions, love, empathy, friendships, romance, therefore everything that is not a part of the rational history, is the privilege of the greatest number of less rational individuals. The ruling layers supply them abundantly with novels, films, series, and reality show programs, a combination of cheap romance and violence, because, anyway, consumers of this shed do not see and understand anything other than limited, dirty everyday life. It is their destiny, as Dostoyevsky would say in 'Crime and Punishment', to be history material at best.
This does not mean that in history we do not encounter significant events that have been caused by illogical behavior, for example, passions, love plots, unrealistic ambitions, greed, madness, ideological blindness and the like. However, that, in no way and not for a long time, could have disrupted either the flow or the meaning of history.

\section{Universe is a latent self-awareness}

What does philosophy say about the facts that characterize the period of modernism? How does it relate to violence, imperialism, physical destruction of entire nations and civilizations, attacks by the powerful on the far weaker and the like? Is there any historical justification for this, what Hegel hinted at, Marx's conception of historical necessity?

Before any further consideration, we here support the basic meaning of Hegel's thesis, that the universe is a latent self-awareness from which life and self-awareness necessarily emerge. For this reason, it is wrong to talk about the dichotomy "dead-alive". To say that the matter around us is inanimate is also true, as to say that our hair, our bones, etc., are inanimate, or that in our body existing minerals (iron, zinc, copper, etc.) are inanimate. Could man survive without the "inanimate" rays of the sun or without "inanimate" oxygen? After all, the human body is inorganic, "inanimate" and would remain so if it were not for "that something" that precedes everything material. If it is true that self-conscious life forms must necessarily, eventually, appear anywhere in the universe, this, again, entails the existence of a single Mind that precedes all that we are. He, according to Hegel's conception, after long historical wanderings, trying out the persistently possible historicity of many civilizations and peoples, was finally embodied in the West. In any case, it must be clear that mind, nature and history, and what Descartes masterfully expressed ("Deus sive natura"), are one, inseparable.

\section{One and a multitude}

In the 1970s, the political motto of UNESCO was 'Plurality of thought, one world' (which, 
in spirit, corresponds to the Latin saying: "Gens una sumus"). Of course, the world remained divided and opposed. Nevertheless, despite all the division, humankind, from the "Stone Age" to the present day, has thrived in many respects.

The dualism: One - Multitude, belongs to the basic sources of conflict and violence. 'One' is finally prevailing everywhere and on all levels, but with great human suffering and sacrifice. Let us remember the process of uniting many countries, the process of adopting rationality as the supreme criterion of behavior, etc. In the modern age, part of the West gave full meaning to the unity of diversity. The European Union has its own fundamental, common principles, and yet its members are, in the most important things, independent. We said, however, that too much freedom of EU member states makes this political-economic entity powerless in relation to the centralized, hierarchical political structure of the U.S., Russia and China. Thus, the citizens of the United States consider themselves Americans, citizens of Russia as Russians, and citizens of China as Chinese. By contrast, EU citizens do not consider themselves Europeans but French, Germans, etc. That is why the power of the EU only manifests itself in symbiosis with the United States.

It is undeniable that one of the key elements of Western dominance was rational monotheism. Greek thought, along with all the gods of Olympus, insisted on one, from the pre-Socratic concluding with Aristotle. With Plotin, Greek one is theologized and commemorates the entire middle Ages. In the age of modernism, through formal, political democracy, the possibility of all humanity was supposedly realized. The competitive variant of capital-relations was made possible by the "cunning Mind", and the neocolonial exploitation of most of humanity, from the point of view of everyday life, was inhumane, gave material assumptions for the further, civic development of a dominating civilization. Everything, finally, in the middle of the XX century stabilized in the "welfare states". There was also a détente among the two opposing blocs, soviet and Western, and the violence that was occasionally used to maintain such an order took place primarily in the zones of influence of the great powers.

The spirit of 'One' was realized through scientific paradigms, organization of work, hierarchical relations in macro and microenvironments (state, supranational communities, families, informal groups). All the emerging forms of such manifestation, in socialist, capitalist and non-aligned countries were subjected to the spirit of the West. This is so much truer that even the elites of the world "periphery" were also educated in developed societies by adopting their values and ways of functioning. Western languages (especially English), computers, civic democracy, urban solutions, cultural patterns in behavior, dominated the world. No one could pretend to be a leader and/or authority of any kind and anywhere, unless they represented the values of the West in one way or another.

Geography, religion and philosophy of the West

The Western world is also known as the Occident (from the Latin word occidens, "sunset, West"), in contrast to the Orient (from the Latin word oriens, "rise, East") or Eastern world. Geographically, chronologically and religiously, the West refers to that western part of the Roman Empire, which emerged from its division, which occurred in 395 AD. Today, by the West, we mean a whole group of countries in Europe, North America and Australia. However, we underline, for us, the West represents first of all one concept, and less one geographical, or one ethnic whole.

The characteristics of the West, and primarily his Mind, are distinguished by three elements: its rationality, its paradigmatic character, and its utopian character. Its roots are twofold: Christianity (including Judaism, Greek and Roman roots) and Hegel's classical-idealistic system.

Christianity today is a practical business religion. Protestantism is at the forefront of this, Catholicism does the same, but it hides behind moral flounders and in Orthodoxy, it is only in its inception. It postulates two states: God and the secular (Augustine imagined the Church 
as a spiritual City of God, distinct from the material Earthly City). If there used to be a domination of the religious over the secular in the west that, historically, did not last long. This balance between these two phenomena was particularly reflected in the middle Ages in a number of European cities-states. After Augustine, Tom Aquino definitely disrupted this balance by prioritizing the mundane. He introduced Aristotle's formal logic to medieval universities. It is obvious that logic and faith are at odds. Generations of students were leaving the university with a developed critical thought, putting Christian dogma in doubt. The repression of the Inquisition was harsh, but over time, it had to lose the battle. From this conflict, the teachings and the repressive faith came the Enlightenment. It, together with the action of aggressive capitalism, became the basis of today's scientism that enabled the West, and with the help of rational bureaucracy (Weber), dominance over the rest of the world.

Hegel's philosophy is the philosophy of civil society as the last stage of humanity without further history. The West was delighted with Hegel's attitude presented by Fukuyama in his book The End of History and the Last Man, because it meant that after capitalism there would be no creation of a new, classless society. Hegel, in addition, indebted the philosophy of history with three other things.

First, he asserted, through the metaphor of servant and master, that all interpersonal relationships are power relations.

He introduced, in addition to Aristotle's formal logic and, on Heraclitus-based, dialectical logic./7/

Thirdly, and what is extremely significant for this work, made the division of societies into historical and non-historical.

-In the Phenomenology of the Spirit, Hegel says: "The relationship between two distinct, selfconsciousnesses beings is therefore determined by them giving each other proof of themselves (...) fighting for life and death (...). Only she, by putting herself in the game of life itself, was thus redeemed, and freedom was disclosed.
Certainly, one who has not put life at play can be recognized as one face, but will never know the truth (of recognition).

The outcome of this struggle is manifested in the form of the emergence of two different consciousnesses, one self-possessed, which we can call the master, and the other, not the selfpossessed, who is destined to become a slave (servant)." /8/

Hegel undergoes three stages of this struggle: 1) Desire, where self-consciousness is directed at things other than itself; 2) Masterslave, where the self-consciousness is directed at another that is unequal to itself; and 3) Universal self-conscious, where the self-conscious recognizes itself in another.

- For Hegel, history is minding and takes place dialectically by scheme: thesis-antithesis-synthesis. Hegel poetically says in The Phenomenology of the Spirit that the Mind was plunged into the night of its self-consciousness but, starting anew at a higher degree of its existence, it also preserved in memory a fraction of what it had previously been.

Marx, who, in his own words, "put Hegel's philosophy on its feet," sees the dialectic of history as a sequence of economic eras. History first, takes the form of a paradigm that is a set of fundamental patterns on which the functioning of a society is based (for example, slavery, feudalism, and capitalism), having its real side - production forces and relationships - as well as appropriate ideological superstructure.

Over time, some paradigm becomes overcome, full of contradictions, dysfunctional, resulting in the creation of a new paradigm. This is manifested as a conflict between forces, supporters of the old paradigm and those who are carriers of a radically new, more advanced way of life, for example, a conflict between feudal lords and representatives of civil society that has formed within feudalism. Theoretically, this can be presented as a conflict between thesis and antithesis, the result of which is synthesis - a new, more advanced paradigm. /9/ Of course, this is only a theoretical scheme of history and does not play out line- 
arly in appearance; has its aberrations (inquisition, Nazism, gulags), but, ultimately, a new, more advanced paradigm prevails.

\section{Historical and non-historical peoples}

In fact, the limitless development of science and technology had it start from feudal society. When the social framework of feudalism began to prevent this development, the bourgeois revolution became necessary. Actually, man had to become free from the feudal attachment to land, and free from the means of production. The bourgeois revolution accomplished this double freedom by making the feudal serf the industrial worker potential and bringing rationality to power; it was the first time in history that rationality (that appeared as economy) took over politics. In other words, liberal capitalism based on competition of individual capacities replaced the rigid feudal system of which the main social value was heredity (any idiot born as a noble automatically belonged to the ruling class). The merciless competition of intelligence and skills on the market (social Darwinism) became the most productive system in history (rationality in power $=$ modernism $=$ capitalism $=$ limitless progress of science and technology).

- Finally, we highlight Hegel's thought of historical and non-historical peoples, which he elaborated in 'Philosophy of History'. /10/ Europe is overwhelmingly rational in relation to the rest of the world, leading humanity on its path of self-illumination towards ultimate spiritual goals within civil society. In relation to European civilization, other nations have no history of their own. Even Marx, in the 'Communist Manifesto', supported this thesis of Hegel, arguing that other nations are barbaric, and that their emancipation must pass through bourgeois emancipation!

"The bourgeoisie has subjected the country to the rule of the towns. It has created enormous cities, has greatly increased the urban population as compared with the rural, and has thus rescued a considerable part of the population from the idiocy of rural life. Just as it has made the country dependent on the towns, so it has made barbarian and semi-barbarian countries dependent on the civilized ones, nations of peasants on nations of bourgeois, the East on the West." /11/

Now everything becomes clear. Only European civilization has a historicity that is dialectically realized through conflicts between old and new paradigms. So what are non-historical peoples for? They are condemned, either to destruction, or to exploitation by the West to make the meaning of history easier to achieve.

A textbook example of this is the tragic fate of the people who were inhabitants of both Americas at the time of the Western colonization of these two continents.

The invaders of the Iberian Half-Blood (and then British and French), committed in both Americas, one of the greatest massacres in all of human history. Bartolomeo de las Kazas, only when viewed the Kingdom of Mexico, baptized by the name of New Spain, wrote in 1542:

"Over these forty years, more than twelve million souls have died unjustly, due to tyranny and hellish misdeeds by Christians. Over the course of twelve years, the Spaniards have slaughtered more than four million inhabitants, women, children, young and old with a knife or spear, or burned them alive... Hellish abuse and actions, they all intensified more from the beginning.

In Brazil, the slaughter claimed fewer casualties, because the Indians, most often scattered in the forests, were unable to provide any more resistance to the invader. Yet of the 6 million Indians in Brazil estimated upon the arrival of the enslavers, about 200,000 were burned today: or an extermination of a million and every century! Din Tomas Balduino, 1980shouted alarm: 'It's about killing one people... In this war they used all weapons: lasso, machine gun, napalm, arsenic, small-pox virus... transfers and deportations.' " /12/

The meaning of the historical violence against non-historical peoples

If, therefore, the first historical goal of Hegel's Mind is to preserve the human species from natural disasters (movies speak, for example, of meteorites that could destroy the 
planet, and defense would be nuclear rockets operating in space) and from deadly diseases, then it is clear that western development of science and technology is the best way to eliminate these types of dangers. To this degree of development, obviously, non-historical peoples could not reach civilizations of the Aztecs, Mayans, Incas, Aborigines, American Indians, etc.

In other words, Hegel's thesis is utterly true in the above examples. We can ask ourselves, for example, how is it that Europeans discovered America and destroyed existing civilizations there, and the reverse did not happen? Why didn't civilizations there discover Europe and conquer it? Why didn't the Aborigines of Australia conquer the West? Why didn't black people enslave white people and stuff? How is it that at the end of the nineteenth century Europe held under colonial administration 90\% of the rest of the world?

It is obvious that European (Western) absolute rationality is that of the differentia specifica that explains everything. Closing your eyes to these facts is tantamount to nonsense and/or demagogy. Five hundred years of reckless exploitation of former colonies by the West had, therefore, not only a swaddled, but also a moral dimension. The suffering of former colonial peoples is, from the point of view of the usual notion of morality, extremely inhuman and unacceptable. However, historically speaking, a suffering has no any ontological value. Until the conditions for the transition of a civilization to a higher stage are created, suffering and revolt remain trapped by the existing paradigm. The revolts of slaves within slavery were barren. Likewise, two basic antagonistic classes of a society, lose all significance when transitioning to a higher social stage, and new class relationships occur. For example, with the emergence of feudalism, slave owners and slaves are replaced by feudal lords and serfs; in civil society bourgeoisie and proletarians come instead of feudal lords and serfs.

Western history has its end in civil society. Historical morality imposed and led by Western elites, whose first goal is to preserve humankind primarily through the development of technology and technology, carries immensely greater weight.

Well-meaning people, as well as abstract humanists and demagogues, will argue that this way of thinking is scandalous, inhumane, uncivilized, genocidal and the like. Rationality, however, cannot help but eliminate anything that is insufficiently mindless and mindless. In the conflicts between Australopithithus, with a brain volume of $450 \mathrm{~cm}$ cubic and Homo habilis whose brain volume was $750 \mathrm{~cm}$ cubic, these last had to be winners. Rome, which adopted Greek culture and developed rationality to perfection, dominated the entire barbaric world at the time. The West, thanks to rationality, colonized the rest of the world, and today only, those societies that accept and apply the basic rational flows of the West are maintained and prospered.

By the way, the sufferings that have affected those who have suffered defeats in conflicts with the more rational of themselves have no historicity!

Let us be honest! In addition to pathetic individuals, who today really cares that the United States originated on land hijacked from Indians (Native Americans) and on their death; some claim genocide against Indians. /13/

Moralistic theories that see imperialist violence as a basic problem of international relations, may explain many events, but they have little practical value. In fact, there is no hope that, for example, the state of (neo) colonialism will be abolished either by the Enlightenment action of "humanistic prophets", or by violence against imperialism.

Historical violence has a very different meaning. When moving from one paradigm to another often takes the form of (revolutionary) wars. Wars between rational societies are useful because weapons are perfected through them, which contributes to the development of science and technology. The former wars between rational and other societies led to the subjection of these last, which enabled their exploitation and further development of rationality. The anticolonial wars that resulted in decolonization are a great deception. Colonial powers have come to realize that it is better to give these countries independence and exploit 
them through market mechanisms than to keep them occupied. Throughout history, wars between non-historical societies, especially those within missing civilizations, have unnecessarily burdened historiography. The current wars that are fought between dominated states are historically useful because in them the great powers try to perfect their weapons.

At this time, there are much bigger problems for humankind than imperialism. The advancement of science and technology requires not only increasingly sophisticated weapons of mass destruction, but also the scientists putting themselves in function of political and/or economic powerhouses.

We are not bringing up anything unusual here. We are just establishing the facts. Western elites of modern times based on rationality have been in power for several centuries. War elites, barely consisting of a few thousand people, can destroy, but also defend the entire planet from elementary disasters. Elites in the realm of genetics create an entire world of new living beings, quite different and more dangerous than we know them. "Intelligent machines", have already replaced those who did the most ordinary jobs, and thus replaced many intellectuals: doctors, mathematicians, architects, the most diverse categories of engineers, even chess players.

On the other side of the mirror, this progress has in no way improved the conditions of the subdued. When you look at what is happening to them, we are establishing a multitude of fratricide conflicts that will cause tens of millions of people to lose their lives every year. More than that, serious clues, lead to the thought of wars, famine, and other plagues, all of which seem to belong to an insane eugenic population purification strategy, worked out on a planet-wide scale. Whatever it is, the West has so many comparative advantages over former colonies that it can still dominate them. Currently, the most talented personnel from a large number of developing countries who are eager to work in scientific, Western institutions also provide its scientific technological development; the most cynical thing is that in their own countries they would remain unemployed and ridicule their irrational, parasitic bureaucracy.

Summary of the first part: The history of the West is the history of the world

Western civilization, governed by the "cunning Mind", until now, has exploited and destroyed those civilizations that do not have a historical perspective. It did so that non-historical societies would give way to a single civilization, which would fulfill essential historical tasks. She forced, above all, the inconspicuous and unlimited development of technology, technique and technology, which constantly reduces the risk of extinction of humankind.

More specifically, until the recent emergence of postmodernism, the history of Western (Judeo - Roman - Greek - Christian) civilization, was also world history, which, in essence, had to be exactly as it was. This, finally, means, completely in Hegel's spirit, that throughout history, Western violence against the rest of the world has been a "conditio sine qua non," a necessary condition for the freedom of humanity.

Note 1 . We have already said that rationality is a characteristic of all nations and civilizations. The fact that many societies have not taken this path are reasons varied: geographical, climatic, religious, national, specific. There were civilizations that were once far more advanced than the West. For example, Arab civilization (medicine, philosophy) and Chinese (paper, printing, gunpowder, shipbuilding). However, in The Arabs, theocratic, Islamic ideology has stopped this progress, and in China mandarin, deep-rooted bureaucratic rule has done so. The advantage of Europe, among other things, was that it knew how to value and assimilate into its rational system to which everything else was subordinate, all the valuable achievements of other peoples and civilizations.

Note2. The philosophy of history should be distinguished from historical chronology. Unfortunately, the education system, in all countries of the world, is burdened by history. Students must learn a large amount of events and 
processes, especially those concerning non-historical people, which they will not need for nothing. Instead of historical chronology, the philosophy of history should be taught and facts should fit within it. However, those who make education systems are part of a government that has no interest in making thinking personalities out of young people.

\section{PART TWO}

Postmodernism, the Twilight of the West and the New Leviathan

Postmodernism, despite its apparent resemblance, is a fundamental break with modernism, a classic capitalist epoch. It means irreversible social confusion due to the increasingly difficult functioning of the market economy, and the disappearance of the Christianity as the very essence of the western civilization. Let us consider the facts.

Sodomy as a sin has been one of the postulates of God's thought for three thousand years. Today it is punishable to mention this as a sin. Marriage, as the natural union of man and woman, was one of the foundations of Christian thought. Today, Catholic countries such as France, Italy, Ireland and Croatia, have renounced this and accepted homosexual marriages as equal to heterosexual ones.

These may be the "new human rights," but they are certainly neither divine nor Christian.

A country that has turned religion into a business and that is at the forefront of the destruction of Christianity by insisting on the "new human rights" and the "multiculturalism" is the United States. This leader of the West, by entering the world stage of China and Russia, has lost the monopoly of the world superpower. Many countries of the European Union, notably the leaders of Germany, Great Britain and Hungary, Merkel Brown and Orban, have made it clear that multiculturalism is dead.

\section{The West is losing its identity}

As said, West replaced its Christian identity with the ideology of "new human rights" and became impersonal. Taking advantage of freakish legal possibilities and political correctness, various minority groups took over the social and political scene. In Europe, this is especially true for LGBT and (mainly) Muslim immigrants, who together make up to $15 \%$ of the population. They seek to impose their particular rights overall society as if they were universal. Immigrants are bound by occasional terrorism as well as repeated sexual assaults on women, covered up by the authorities. /14/

As far as the LGBT, population is concerned, given the media noise generated around them, it gives the impression that they are the ones who created history and enabled the reproduction of humankind. Given that their campaigns often take cartoonish forms $/ \mathbf{1 5} /$, this has caused (and causes) social and political chaos in the West with many divisions and conflicts.

With laws allowing homosexual marriage, the meaning of marriage and family has been destroyed. Heterosexual marriage allows legal regulation of parents and offspring. "Classic" marriage is not based on any kind of sexuality, but only on heterosexuality, because only it allows fertilization. Homosexual marriage is barren, no children from their union! In this regard, it completely does not matter whether two homosexuals or two passionate anglers will form the "marital"union. The result is the same: there are no children from their relationship. So why can't two passionate anglers form a "marriage" union, or, for another example, why can't two same-sex people who love the Mediterranean diet do the same? Any set of same-sex individuals who have some common affinity has the right, under current laws, to marry! Finally, two passionate anglers who have served "matrimonial" union can also adopt and raise children with care and love.

The new Leviathan has become so powerful, that he is capable of abolishing the people! Here's an example.

In California in 2008, the people voted against gay marriage in a referendum, and it lasted several years until the U.S. began to lose primacy worldwide, and the New Leviathan 
began significantly strengthen it. His exponent, the high judicial authority, ruled that the people could not make decisions that were illegal in a referendum!

"Introduced by Senator Mark Leno on February 21, 2014, SB 1306 repealed Sections 300 (AB 607, 1977), 308 (The Marriage Recognition and Family Protection Act, author by Sen. Leno), 308.5 (Prop 22, California Defense of Marriage Act) of the Family Code, and amended Section 300 to be genderneutral among other sections as well. The legislation removed the statutory reference to marriage as a $u$ nion "between a man and a woman" from the states' Family Code and updated the law with genderneutral terms to apply to same-sex marriages as well as heterosexual ones.

During its passage, some concern was expressed that, by repealing the California Defense of Marriage Act, SB 1306 breached the separation of powers as the Legislature would be repealing an initiative passed by the voters. However, the consensus of the Assembly Judiciary Committee was that the voters are no more able to pass an unconstitutional, and subsequently enjoined, statute anymore than the Legislature can."/16/

Thus, the postmodern perversion of "democratic" relations has gone so far that one handful of people who are not even elected by the people can, in the name of legal independence (Montesquieu, separation of powers) impose something against the wish of the people! Most peculiar is the fact that in one society there is $5-6 \%$ of the gay population and that their will, and this example shows it clearly, is more important of the will of the largest part of the people.

Marx said that, over time, the ideological superstructure is alienated from its base and imposed on it.

Note. The statute definition of marriage in California is now the following:

„Marriage is a personal relation arising out of a civil contract between two persons, to which the consent of the parties capable of making that contract is necessary."

Sexual orientation of a barren nature is a private matter of each individual, such as, as far as human reproduction is concerned, a barren nature of the union of two passionate anglers. Without children, there is neither man nor humanity, nor there ever one! Add that "two dads" and "two moms" are not parents; they are guardians, foster persons. Luckily, humanity was based on heterosexuality; otherwise, it would not be there.

What to say about the "third sex"? Namely, if someone notices that he/she is neither a man nor a woman, he/she has the right to state in his/her personal map that, sexually, he/she is "something else". Alternatively, someone can be a man and feel like a woman, and indicate it in a personal map! Let us think about a number of unpleasant situations that one such person could provoke with his behavior. For example, does a man, considering himself a woman or a being of an indeterminate sex, have the right to use a women's toilet?

Or, if a man is sentenced to prison and considers himself a woman, will he be placed in a male or female prison?

Finally, what to say about exaggerations ("zero tolerance") concerning "sexual correctness". A 6-year-old student, Hunter Yelton, was suspended on allegations of sexually harassing a 6-year-old girl, for kissing her on the cheek, at Lincoln School of Science and Technology in Cañon City, Colorado. The two families dispute whether the contact was consensual.

Just to mantion. In Scotland, children aged four and over, have the right to choose their own gender without parental consent, Instructions on this exists in all preschools and primary schools of Scotland.

Obviously, the West reached the twilight zone. The mind capitulated to the non-minded. The first one, after millions of years of hard work, managed to form a civil society, especially its institutionalized humanitarian aspects. Nothing could be more advanced than a civil society that proclaimed the equality of all human beings before the law. In this sans, Hegel is right about the end of history. Consequently, the role of Mind as a historical actor can no longer manifest itself. 
The New Leviathan

The reaction to the decline of the West meant, at first, a defense of western civilization. The infrastructure levers of western states put together politicians, presidents of powerful companies, scientists, rational bureaucracy, intelligence services, financial and health institutions, the scientific revues, and the media (including social networks). The result was the formation of an informal, gigantic, powerful political organization, a New Leviathan that, by all indicators, firmly decided to restore the former power of this civilization.

Things did not stop there. This association also included the unimaginably rich ideological eugenic theorists of the Hitler's type who would, "in the name of the new humanism"; significantly reduce the world's population. /17/ Of course, western states still exist, life seems to take place under the same schemes, but their handlebars are only formally in their positions, while their real activity is to manage the New Leviathan, unseen in history so far.

Remark. It is clear that any state has hidden, parallel structures of government. The informal ones, they do not always agree with what their country does. However, this is about a parallel structure of government formed from the elites of all countries of the decaying West. In fact, if some state figures and measures are acceptable for the New Leviathan, then he accepts them without question. Otherwise, its resistance is violent and often effective.

The aggressiveness of the New Leviathan was clearly seen in the case of former US President Donald Trump. He wanted to weaken the power of the political establishment and, as in the era of classical liberalism, subordinate it to the economy. Then, he did not want to fight wars, and he wanted to improve relations with Russia! For the mighty of the New Leviathan, it was a triple mortal sin. As loyal disciples of Carl Schmitt./18/, they condemned Trump's economics. Schmitt also insisted on the necessary conduct of military actions against Western-harmful "disruptive factors," and the leaders of the New Leviathan recognized Iran, Russia and North Korea in "disruptive factors." They thought Trump was too kind to them. At the same time, on the theoretical front, Schmitt felt that making political enemies was the basic thing in political science. By contrast, Trump wanted reconciliation with Russia, the West's main and unchanging political enemy.

The aggression against Trump lasted four years of his tenure. He was criticized day and night as the main enemy of the United States and the West. "CNN," "New York Times" and "BBC" led the way, seizing on all possible negative qualifications.

Trump has said all along that he is fighting a "deep state." /19/ He was on the right track, but he made substantive mistakes and therefore could not succeed in his struggle. What he was up against was a global state, not a national "deep state." /20/

In addition to crude, unequivocal attacks, this criminal octopus also used an "intellectual" deception and demagogy.

Note. American presidents are "straw dogs." They are governed by a "deep state"; they are especially in trouble, if they oppose the military-industrial complex (Eisenhower). Everyone who tried to do that was disabled. Many historians, Kennedy acolytes, and celebrities, such as movie director Oliver Stone, have claimed that the withdrawal of 1,000 U.S. soldiers from Vietnam was the beginning of Kennedy's plan to withdraw completely from South Vietnam after he gained re-election in 1964 and cited NSAM-263 as evidence for that plan. Nixon was forced to resign after ending the Vietnam War and launching a détente with China. Clinton was disabled after announcing a 30\% cut in budget funding for the military, a bill banning individual gun purchases, and Social Security and all Americans. We already know the fate of Trump

\section{The great Reset}

At the annual summit of the World Economic Forum (WEF) held in June 2020, some of the world's most respected businesspersons sent a "humane" message to the global population that the time had come for a big reset of our main problems. Apparently, after Kovid 19 , who opened our eyes to the unjust society 
in which we live, "The Great Reset", or reform of the capitalist way of production, would be a "revolutionary" response to the basic existing injustices of today.

Klaus Schwab, founder and CEO of the WEF, sent the following notice to the world: "In short, we need a big reset of capitalism." Schwab also said that "all aspects of our societies and economies", from education to social contracts and working conditions, must be reshaped. In a joint video message on YouTube, many dignitaries said they take the COVID-19 pandemic as an opportunity for a reset in which there is no return to the status quo.

This is not even science fiction. For capitalism to be "humanized", the following would be needed.

- To rid developing countries of debt bondage.

- To help them develop until they are able to engage in competitive market relations.

- For the world's major stock markets to stop deciding on the life and death of the population of developing countries. Namely, when, for example, the price of agricultural products on stock exchanges in London or New York falls by several dollars, in many developing countries that live exclusively on agriculture and with it go to the world market, immediately, due to reduced incomes, several tens of thousands of people die.

- It would take the world's big companies that rule the world to forgo profits in trading with developing countries.

- It would take a ban on the sale of weapons, the most profitable business of developed societies, to developing countries.

- The world's superpowers should stop trying out their new weapons in the provoked wars fought in developing countries.

- The world's superpowers should cease their military interventions in developing countries by overthrowing legitimate authorities and establishing puppet regimes.

-At the ontological level, it should be explained to young generations through education that market competitiveness and profit are socialistic principles, that inexorably and e- verywhere they produce severe social inequalities and class stratification of society, even in highly developed countries.

So in the U.S., a country where residents of big cities stumble across countless homeless people, about forty million people live below the poverty line, have no basic health insurance, and often no residence.

- It should be that every individual in the world contributes to the work of society according to its abilities, and that as a dignified human being it receives according to needs.

- Finally, it should be that those "1\%" of the most powerful businesspersons who gather regularly in Davos, and who own the bulk of the world's capital, first reset themselves. They should give up some of their wealth and provide conditions for public services such as education, health, science and culture to be accessible to all and for this to cease to be a 'market commodity'

Overall, in order to solve this all with a "big reset", capitalism should be abolished.

Apparently, illusory "human capitalism" is not the right message from Schwab after all. We are far more disturbed by his idea of implanting new technologies into man. /21/

The historical violence that resulted in a civil society that had been in severe trials in the past century - two world wars and Nazism - decreased significantly with the emergence of "states of prosperity". Even developing countries, through the non-alignment movement, have benefited from it. In contrast, wanting to restore luster to the West, the New Leviathan's current rule of the postmodern world is turning into pathological behavior! It is obvious that in the times ahead, the intended reduction of the population, whose victims would be, for the most part, the inhabitants of developing countries but also the "undesirable" ("superfluous") inhabitants of developed countries who will practically be unemployed in a future society without work. /22/ Only the top science will be promising, but the number of people in the domain will be decreasing and access will be more and more exclusive. 
New Leviathan Deliberate Victims - Didier Raoult Case

The New Leviathan is not just about deception and demagogy. He massively drives people into sickness and death. The Didier Raoult case will explain it best.

Didier Raoult is French, professor of the faculty and runs the largest tropical and infectious disease clinic in the country in Marseille (Unité de Recherche sur les Maladies Infectieuses et Tropicales Emergentes). As far as his nature is concerned, he is one of the most cited people in the world. In scientific journals, he published thousands of articles! In Marseille, people adore him. He is also highly respected in francophone Africa where he constantly goes and where he has improved the health systems of these countries,

When Covid 19 appeared, he began treating patients, in the early stages of the disease, with a combination of HCQ and azithromycin, the treatment was effective, curing more than $95 \%$, and mortality extremely low. Here is the result of a Didier study involving more than a thousand patients./23/

\section{Background}

In France, the combination hydroxychloroquine (HCQ) and azithromycin (AZ) is used in the treatment of COVID-19.

Methods

We retrospectively report on 1061 SARS-CoV-2 positive tested patients treated for at least three days with the following regimen: HCQ (200 mg three times daily for ten days) + AZ (500 mg on day 1 followed by $250 \mathrm{mg}$ daily for the next four days).

Results

A total of 1061 patients were included in this analysis (46.4\% male, mean age 43.6 years range 14-95 years). Good clinical outcome and virological cure were obtained in 973 patients within 10 days $(91.7 \%)$. Prolonged viral carriage was observed in 47 patients $(4.4 \%)$ and was associated to a higher viral load at diagnosis $(p<.001)$ but viral culture was negative at day 10. All but one, were PCR-cleared at day 15. A poor clinical outcome (PClinO) was observed for 46 patients (4.3\%) and 8 died (0.75\%) (74-95 years old). All deaths resulted from respiratory failure and not from cardiac toxicity. Five patients are still hospitalized (98.7\% of patients cured so far). PClinO was associated with older age (OR 1.11), severity of illness at admission (OR 10.05) and low HCQ serum concentration. PClinO was independently associated with the use of selective beta-blocking agents and angiotensin II receptor blockers $(\mathrm{p}<.05)$. A total of $2.3 \%$ of patients reported mild adverse events (gastrointestinal or skin symptoms, headache, insomnia and transient blurred vision).

Conclusion

Administration of the HCQ+AZ combination before COVID-19 complications occur is safe and associated with a very low fatality rate in patients.

Note. At the beginning of the pandemic, in 2020, the Chinese treated patients with $\mathrm{HCQ} / \mathrm{CQ}$.

It should be said that HCQ is an antimalarial drug that costs a couple of euros! It has been used for seventy years without any consequences for the sick!

This did not correspond to the New Leviathan who, in all likelihood, wanted people (old, poor, "colored ") to die, not to stay alive!

Two philosophical approaches to Covid 19 met here. Didier felt that patients should be treated as soon as the first signs of the disease appeared and provide them with the best that the doctor can and knows how to do. When the disease is at the very beginning, it can also be treated out patiently. Didier had a team with him that was fully committed to patients.

The philosophy of the New Leviathan presented through the World Health Organization (WHO), was that when a person complained about signs of illness, he/she was sent home and that he/she was taking paracetamol. If things get worse, he will report to the hospital. Unfortunately, if the infected came to the hospital, it would be too late for many. Since there were many people in the risk group, the crowd would be indescribable, the conditions for treatment none some would end up on ventilators, and that meant almost certain death; only one in seven patients would survive. 
Since Didier was a celebrity, it needed to be psychologically destroyed and scientifically discredited. From all western countries, negative opinions and studies were coming in about his method of treatment. Didier was treated as a mediocrity, a false scientist, a person who, by his method, sends people to their deaths for, supposedly, the severe cardiovascular problems that his drug causes! The attacks on him brought together celebrities from the world of medicine, genetics, and the media. Still, there was a lack of "scientific confirmation" of these attacks. The new Leviathan hired one of the world's top scientific magazines, Lancet, in order to discredit Didier Raoult. That is here the farce begins.

"The Lancet is one of the oldest and most respected medical journals in the world. Recently, they published an article on Covid patients receiving hydroxychloroquine with a dire conclusion: the drug increases heartbeat irregularities and decreases hospital survival rates. This result was treated as authoritative, and major drug trials were immediately halted - because why treat anyone with an unsafe drug?

Now, that Lancet study has been retracted, withdrawn from the literature entirely, at the request of three of its authors who "can no longer vouch for the veracity of the primary data sources". Given the seriousness of the topic and the consequences of the paper, this is one of the most consequential retractions in modern history. "/24/

Before a fake study with, allegedly, 90,000 subjects, was withdrawn, in France and in some other Western countries, Didier treatment was banned (prohibited use of HCQ), which was never revised. After the study was receded, it was said that a new study would be done, but there were no whirlwind volunteers for such a thing; they were afraid of getting some heart disease.

Everything that happened to him, Didier Raoult published in his book Carnets de guerre, COVID 19 (Michel Laffon, Paris, 2021).

Note. Almost every day there is news of new medicines that would combat the coronavirus pandemic. However, two already known drugs are now in Germany hopeful of successful treatment.

Among others, the German government has purchased 200,000 doses of two medicines, and the price is - 2,000 euros per dose. Expensive drugs promise a lot. Last October, a cocktail of these corona drugs cured US President Trump. He was treated with 'REGN-CoV-2', a pharmaceutical company Regeneron cocktail of antibodies derived from the blood of cured patients. It is given intravenously, reduces the amount of viruses and blocks their multiplication.

It was claimed that this drug is in the trial phase, therefore unsafe, but who would dare treat the President of the United States with something untested, unsafe, and the like. On top of that, the president of the company that makes the drug, Leonard Shlifer, is a personal friend of Trump's.

Coming out of the hospital, Trump declared that he would do anything to make this drug available to all Americans! At the time, Regeneron therapy cost $\$ 30,000$ (thirty,000) dollars. Since then, 100,000 Americans have been cured with the drug.

U.S. health authorities have approved the use of medicines as a matter of urgency, and the procedure for granting a license is ongoing in the European Union. It is a drug Bamlanivimab from Eli Lilly and the drug REGN-CoV-2 made by the company Regeneron.

Both drugs work in the same way: they consist of antibodies that bind to the coronavirus where it clings to the human cell with its "tentacles". This prevents the penetration of the virus into the cell.

So-called momoclanal antibodies are produced in the laboratory. They are all the same and attack a precisely defined target in the virus.

The drug of the American company Regeneron contains two types of antibodies. This company claims that therapy with this drug reduces the burden on the organism with the virus and that this leads to a rapid decrease in symptoms, reduces mortality by $70 \%$, and the length of treatment by four days.

The drug of the American company Eli Lilly contains only one type of antibody. 
Drugs act as "passive vaccination. Treating atrisk patients at an early stage helps to avoid a more severe course of the disease," says German Health Minister Jens Spahn. However, unlike the reaction to drugs made based on antibodies, after vaccination the body develops a mixture of antibodies that can bind the virus in different places. Experts then talk about polyclonal antibodies.

\section{Crime against humanity /24/}

On Monday, September 27, 2021, more than 5,200 doctors and scientists have signed the "The Physicians Declaration," condemning policymakers for authoritarian approaches of forcing a "one-size-fits-all" COVID treatment strategy which is resulting in "needless illness and death."

An international alliance of physicians and medical scientists met in Rome, Italy on September 12 - 14 for a three-day Global COVID Summit to speak "truth to power about COVID pandemic research and treatment." The summit presented an opportunity for the medical professionals to compare studies and assess the efficacy of the various treatments for the Coronavirus that have been developed in hospitals, doctors' offices and research labs throughout the world.

However, many of these medical professionals have experienced career threats, character assassination, censorship of research papers, clinical trials and patient observations, their professional history and accomplishments altered or omitted in academic and mainstream media because of them providing life-saving treatments for COVID patients.

Dr. Robert Malone, who discovered in-vitro and in-vivo RNA transfection and invented mRNA vaccines while he was at the Salk Institute in 1988, read the Declaration at the summit.

"The Physicians Declaration" states:

"We the physicians of the world, united and loyal to the Hippocratic Oath, recognizing the profession of medicine as we know it is at a crossroad, are compelled to declare the following;
WHEREAS, it is our utmost responsibility and duty to uphold and restore the dignity, integrity, art and science of medicine;

WHEREAS, there is an unprecedented assault on our ability to care for our patients;

WHEREAS, public policy makers have chosen to force a "one size fits all" treatment strategy, resulting in needless illness and death, rather than upholding fundamental concepts of the individualized, personalized approach to patient care which is proven to be safe and more effective;

WHEREAS, physicians and other health care providers working on the front lines, utilizing their knowledge of epidemiology, pathophysiology and pharmacology, are often first to identify new, potentially life saving treatments;

WHEREAS, physicians are increasingly being discouraged from engaging in open professional discourse and the exchange of ideas about new and emerging diseases, not only endangering the essence of the medical profession, but more importantly, more tragically, the lives of our patients;

WHEREAS, thousands of physicians are being prevented from providing treatment to their patients, as a result of barriers put up by pharmacies, hospitals, and public health agencies, rendering the vast majority of healthcare providers helpless to protect their patients in the face of disease. Physicians are now advising their patients to simply go home (allowing the virus to replicate) and return when their disease worsens, resulting in hundreds of thousands of unnecessary patient deaths, due to failure-to-treat;

WHEREAS, this is not medicine. This is not care. These policies may actually constitute crimes against humanity.

\section{NOW THEREFORE, IT IS:}

RESOLVED, that the physician-patient relationship must be restored. The very heart of medicine is this relationship, which allows physicians to best understand their patients and their illnesses, to formulate treatments that give the best chance for success, while the patient is an active participant in their care. 
RESOLVED, that the political intrusion into the practice of medicine and the physician/patient relationship must end. Physicians, and all health care providers, must be free to practice the art and science of medicine without fear of retribution, censorship, slander, or disciplinary action, including possible loss of licensure and hospital privileges, loss of insurance contracts and interference from government entities and organizations - which further prevent us from caring for patients in need. More than ever, the right and ability to exchange objective scientific findings, which further our understanding of disease, must be protected.

RESOLVED, that physicians must defend their right to prescribe treatment, observing the tenet FIRST, DO NO HARM. Physicians shall not be restricted from prescribing safe and effective treatments. These restrictions continue to cause unnecessary sickness and death. The rights of patients, after being fully informed about the risks and benefits of each option, must be restored to receive those treatments.

RESOLVED, that we invite physicians of the world and all health care providers to join us in this noble cause as we endeavor to restore trust, integrity and professionalism to the practice of medicine.

RESOLVED, that we invite the scientists of the world, who are skilled in biomedical research and uphold the highest ethical and moral standards, to insist on their ability to conduct and publish objective, empirical research without fear of reprisal upon their careers, reputations and livelihoods.

RESOLVED, that we invite patients, who believe in the importance of the physician-patient relationship and the ability to be active participants in their care, to demand access to sciencebased medical care."

Liberty Counsel Founder and Chairman Mat Staver said, "These medical professionals have been censored and threatened for simply upholding the Hippocratic Oath to 'do no harm.' Throughout history, many breakthrough discoveries that have now become accepted science were initially censored. It's past time to end medical censorship and allow doctors and scientific experts the freedom they rightfully deserve."
Beta coronaviruses - laboratory product

It is certain that for the possible realization of eugenic doctrines imposed by the New Leviathan, nanotechnology and genetic engineering, through the production of deadly viruses, it will play a major role. The hidden rulers of the world have realized that they can govern efficiently and indefinitely, without resorting to the brutal methods of violence so far: police repression, torture and the like. Using laboratory-deadly viruses, "invisible killers," they can manage frightened masses from now on. Moreover, what irony, the masses will look at their rescuers in the criminals (corrupt medics, medical crisis headquarters, local rulers, pharmaceutical companies, international health institutions, and media). The Covid 19 crisis makes this clear. In the span of 18 years, "rescuers" have laboratory produced three, previously non-existent, - beta - coronaviruses, the third of which has caused the seafaring of more than three million people and hundreds of millions infected.

The facts will show, with a high degree of probability, that in this case, it was a laboratory virus, and then it will be seen who benefited the most from it.

At the end of December 2019, a new Coronavirus (SARS-CoV-2) officially appeared, causing Covid 19 and a pandemic of international proportions. However, Philippe Aimar claims the disease appeared a few months earlier, blaming the powerful New Leviathan. Here is what he writes in the introduction to his book. /26/

On October 18, 2019 in Wuhan, the military sports games, inaugurated by President Xi Jinping, open. Several French, Italian, Swedish soldiers, etc., fell ill during the tests.

Exactly the same day in New York begins a simulation of a global pandemic that will bring together, among others, the Bill Gates Foundation, the John Hopkins Center, the World Economic Forum, Avril Haines (former director of the CIA under Barack Obama), George Fu Gao director of the Chinese Center for Disease Control and Prevention, Adrian Thomas vice president of Johnson $\mathcal{E}$ Johnson mul- 
tinational chemistry, and part of the NBC television crew that will simulate the media coverage (via the fake GNN TV) of the "Coronavirus" scenario live from a...Brazilian pigsty (sic). In addition, here is a detail from the script of the New York rehearsal:

"A bat transmits the virus to animals, which will then pass to humans and which will trigger a pandemic with millions of deaths."

Whatever it was, the world's scientific community was surprised, claiming it had never encountered anything like it. This, however, was not true. Let us go in order.

Coronaviruses have been known for half a century. Without DNA genetic material with single-stranded RNA, it turned out that viruses from the 'Coronaviridae' family are parasitic, inanimate creations without metabolism. They got their name because of their appearance, which was beautifully seen by an electron microscope, which, due to their spikes on the ball body, resembled a crown. It has been established that this virus, a parasite, enters the human cell precisely with the help of these, protein spikes, by connecting its sheath and cell membrane, where in this way it would come to life by destroying its 'host'.

It has also been found that common human coronaviruses (four alpha coronaviruses), mainly, cause a mild cold and infections of the upper respiratory system, resembling a common cold.

Suddenly, mild alpha viruses reportedly skipped hundreds (maybe thousands) of years of evolution and turned into murderous foreign bodies! Gene analysis shows that, in addition to the external form, the new coronaviruses have little to do with alpha viruses, so they are called beta coronaviruses.

The first of them, SARS CoV 1, appears in 2002. It spread droplets, in direct contact between two people, attacked primarily the lungs and in a couple of days, the infected patient would be in serious condition. Ten percent $(10 \%)$ the infected died. The infection was completely stopped within a year.

MERS appeared in Saudi Arabia in 2012. MERS or Middle East Respiratory Syndrome, also known as camel flu, is a viral respiratory infection caused by MERS-Coronavirus (MERS-CoV). Lethality was 34.5\%. It was found to a bat infected with a virus that has exactly the same gene structure as the infected camel virus, but no one knows how the infection could have occurred since bats, camels and their hounds have lived in these areas since time immemorial and nothing like this has ever happened!

Finally, after an eight-year interval, a known, third deadly coronavirus beta appears, SARSCoV-2, which is $80 \%$ gene identical to SARSCoV-1.

It has been shown that what is characteristic of the three deadly coronaviruses listed, which occur every eight years, is the fact that in no case could an intermediary be found in order to obtain a spillover of the virus from bats on the camel (MERS), and from bat to human (SARS 1,2). However, the real story is just beginning and includes the fourth artificial, deadly beta Coronavirus!

In the midst of a "cold war" between China and the United States, the worldwide sensation was the news that the two countries had jointly created an artificial beta coronavirus that was extremely dangerous to human health.

This was published in 2015 in Nature Medicine. /27/ The text describes the production of a sustainable and highly pathogenic synthetic Covid virus for humans under the pretext of studying a potential pandemic.

The scientists responsible for these studies are Ralph S. Baric, professor and director of the Microbiological Laboratory at the University of Chapel Hill (North Carolina) and Shi Zheng Li, a microbiology doctor who graduated from the Faculty of Science in Montpellier, now head of the Laboratory of the Wuhan Institute of Virology. In a mouse-friendly coronavirus, these Frankensteins inserted another Coronavirus spike (spike) from one infected bat, allowing the penetration of a new, hybrid virus into the human body, with devastating consequences!

Main part of the Baric - Shi article 
"...To test the ability of the SHC014 spike to mediate infection of the human airway, we examined the sensitivity of the human epithelial airway cell line Calu$32 B 4$ to infection and found robust SHC014-MA15 replication, comparable to that of SARS-CoV.To extend these findings, primary human airway epithelial (HAE) cultures were infected and showed robust replication of both viruses. Together, the data confirm the ability of viruses with the SHC014 spike to infect human airway cells and underscore the potential threat of cross-species transmission of SHC014-CoV."

(It cannot be more clear, E. V.)

This has proven that by genetic engineering we can, without major problems, insert part of the genetic material of another organism into an organism. Thus, for example, the fluorescent jellyfish gene was inserted into a sheep that became fluorescent under UV rays, which was done in 2012!

Here we must mention the Dutch scientist Ron Fouchier who played God - and/or Frankenstein - as well as the aforementioned American Chinese tandem. He genetically modified the deadly A/H5N1 bird flu virus, which has since been capable of spreading among mammals, including man! It has been calculated that the probability of this laboratory, synthetic virus occurring naturally is one versus a billion! /28/

It is similar, again, to the incredible "evolutionary" appearance of three beta corona viruses, one after another within 18 years. The probability of that is so small that it is more likely that some monkey, hitting randomly the buttons on the typewriter, he would have ticked off a set of Dickens parts.

When it comes to the three coronavirus betas mentioned above, it is logical to assume that their creators experimented, created one virus after another, until they produced the one they thought would be the most effective.

- SARS-CoV-1 had a short incubation period of a few days, did not have time to spread, people had to go to the hospital immediately and there this virus was stopped.

-MERS had to be stopped because of high lethality; $30 \%$ of infected people died.

- SARS-CoV-2 was ideal for its dark creators. The lethality was below $1 \%$ of those infected, the incubation period was long, and so its spread could affect the whole world in the short term. Politicians and the media made him bogeymen, crisis headquarters created prisons from the habitat, and pharmaceutical companies, in cooperation with corrupt politicians, stigmatized cheap drugs and early treatment, hospitals filled up and there was total panic in society.

Efficiency of the New Leviathan - people transformed into a herd

„In 1947, Albert Camus published his existential novel, The Plague. Set in the Algerian city of Oran, one of its central characters is a doctor who treats the first victim, quickly coming to see the scale of the threat. He warns the lethargic authorities that they must urgently act. In response, the civil authorities imposes martial law and curfews, and curtailed human rights - banning funeral rites - demoralizing the populace. There are uncomfortable parallels with contemporary events. Oran was locked down and quarantined, stirring and unleashing baser instincts of exploitation, criminality, violence and looting. In 2020, the surreal, dystopian nature of the coronavirus pandemic was stranger than fiction. Thousands of people died each day, while civic buildings and conference centers were being repurposed as hospitals. Scientists, epidemiologists and public health experts argued over the numbers of anticipated fatalities, the closing down of economies, the locking down of communities and the self-isolation of the vulnerable while we asked ourselves when will it end; what will the long-term implications be? Camus' novel poses some of the same serious questions - about what it means to be human, about the effects on the trajectory of our destiny and progress, and how quickly, under the cover of darkness, we will see the erosion of gains democratic, social, communal and personal." /29/

During the pandemic, media and politicians began to talk about the herd immunity. Deep symbolism. The New Leviathan, by spreading the disease and through the totalitarian propaganda, made of the world population a flock of sheep ready to be sacrificed. 
Who was dying and which of those deaths profited? Take the United States, the scientifically and technologically developed country of the planet, where, not to believe, seven hundred thousand people died from this disease, a tenth part of those who were killed by the same infection in the world! Mostly AfricanAmericans, Hispanics and Native Americans, "Indians", died. /30/ Of course, the dead were mostly old, poor and in prisons. Some intellectuals speak publicly about the true genocide of these national and social categories. /31/ More than $90 \%$ of the deaths, not only in the US but worldwide, were over seventy years old, thus significantly exempting social benefits funds, and they were comfortable with the racial structure of the deceased. Then, Covid 19, to a considerable extent, helped Trump lose the presidential election. On top of that, as workers lost their jobs en masse, Western billionaires increased their fortunes, and a number of national economies were destroyed, which will benefit the West the most. /32/

The New Leviathan has shown remarkable ability in other domains during the duration of this disease. Crisis headquarters were created in most countries managed by the World Health Organization. She was practically ordering how the crisis headquarters would behave. There are claims that she underpaid the governments of many countries to introduce many measures that directly encroached on citizens' freedoms. /33/ Pharmaceutical companies that have made huge profits through their vaccines, which are politically colored, /34/, should not be forgotten; seven billion people are scheduled to be vaccinated with three doses!

Let us also mention that, during the pandemic, the World Health Organization has proven itself the striking totalitarian institution of the New Leviathan. In cooperation with the authorities of the largest number of states, the media, especially social networks, and health regional organizations, she banned all opinions that contradicted what she claimed by declaring them "conspiracy theories". In this, "scientific journalists" networked into "factcheckers" organizations played a special role, explaining to the people the "truths" in which they must unconditionally believe. Therefore, she smeared world-renowned scientists, including a couple of Nobel laureates, and banned them from posting their views, or took already published views off social media.

Some things, Hegel argues, first appear in the form of tragedy, and the second time in the form of farce. The actions of the World Health Organization fully fit into this position. The institution has banned anyone from saying SARS-CoV-2 is a laboratory virus for more than a year. However, when one of the powerful of the New Leviathan, an American, Dr. Anthony Fauci, a former Trump health policy adviser, suddenly changed his mind about it, allowing it to be possible after all, no one is barred from expressing such views anymore! /35/

Let us summarize our findings. New evidences about appeared./36/ Who could have done that?

China has had the most prosperous economy in the world for more than a decade, continues in this direction and is ethnically coherent; $95 \%$ of the Chinese are from the Han people. It has its own nonviolent methods of expanding its influence.

Russia has too many internal and external problems: a bad economy ruled by tycoons, problems with Ukraine and Crimea, and above all, it must, as a multiethnic community, be kept from collapse; the whole West would like to have at least a piece of Siberia.

Trump's administration in the U.S. has been clumsy, unsuspecting, funny and contradictory, especially as far as 20th-century Covid is concerned.

On the other hand, the one who benefited the most from the pandemic was the New Leviathan.

- He was rid of one part of the old, "useless" people and freed up many means for social funds.

- He got rid of Trump.

- He got rid of one part of the undesirable, "colored" people.

- He destroyed a number of medium and small economies in the world, from which he will benefit the most through the "help" he will provide to these countries. 
- He made it impossible to treat Covid 19 with cheap drugs directing the world's population toward the vaccine. In addition to the drugs already said, there is ivermectin, which helped India greatly prevent people from dying in mid2021 from Covid 19. /37/

- Pharmaceutical companies, part of New Leviathan, have made billions in profits. Their laboratories, in addition to the corona virus, systematically created new strains, thus maintaining anxiety, fear and panic throughout the world. The result has been the mass vaccination of billions of people, including children, for whom a third dose of the vaccine is recommended. Owerall, new analysis shows that the firms Pfizer/BioNTech and Moderna are charging governments as much as $\$ 41$ billion above the estimated cost of production. Colombia, for example, has potentially overpaid by as much as $\$ 375$ million for its doses of the Pfizer/BioNTech and Moderna vaccines, in comparison to the estimated cost price. /38/

- Billionaires have increased their wealth by several times, and hundreds of millions of people have lost their jobs.

- The New Leviathan realized that with the help of fear of the virus, it is possible to rule people indefinitely. Through the experiment with Covid 19, he knows that for a "handful of dollars" he can buy the bulk of people: governments of many countries, scientists, medical personnel, journalists, and so on.

- He strengthened his organization, which worked perfectly during the pandemic.

-With this "good start", he can continue his eugenic policy of reducing the world's population; so far, "only" seven million have been killed four million in India, and three million in the rest of the world.

\section{Conclusion}

Today, more than ever, it is important the question posed seven decades ago by the German philosopher Horkheimer: "Is humanism possible after Auschwitz"?

Seeing that postmodernism destroys all the most important western civilizational achievements of history so far, Christian foundations, family and universal human rights, the answer is terrifying. The West was, and will remain, humanity's greatest evil and best hope. Due to its absolute rationality, it will continue its genocidal policies, while at the same time the risks of the disappearance of humankind will decrease. As for true humanism for everybody, it is, as the German philosopher Ernst Bloch would say, an unrealistic utopia; there never has been, and never will be. The suffering of some ensure the humanism of others.

On a phenomenological, postmodern level, evil takes the form of the New Leviathan. He is some kind of a global deep state, resolved to restore the former glory to Western civilization at all costs, announcing a war on the "bad part" of humanity. In his mind live phantoms of former British and French colonialism and the U S world policeman. Without realizing that this is not how it works anymore, he wants to destroy a civil society and human rights. This totalitarianism was clearly demonstrated during the Covid 19 pandemic.

The New Leviathan is an extremely dangerous eugenic organization, which, like the god Janus, owns two faces. He is formally forced to act like a "good guy" full of virtues, and on the other hand, as a "bad guy", he tries to fight his rivals for world domination without minding the means. This is the well-known story of the doctor Jekyll and Mr. Hyde.

With his intentions, he gave a new quality to Hitler's pathological racist biologism, who is humanity's greatest evil saw in Jews. The New Leviathan goes much further by wanting to eliminate all the "superfluous" people in the world: "insufficiently rational", old, mentally ill, "colored", poor, and so on. Let us not forget that the West, starting from Darwin and Galton, has a "great" tradition in this matter. At the same time, he is the eugenic US of the theorist Margaret Sanger of the early XX century, Hitler's Germany and Stalin's Russia, which, whether one wants to or not, is a part of Western civilization.

Recently, one "humanist" multi-billionaire, Bill Gates, said in 2010, from whom, at one point, Freud unwittingly spoke "First, we've got 
population. The world today has 6.8 billion people. That's headed up to about nine billion. Now, if we do a really great job on new vaccines, health care, reproductive health services, we could lower that by, perhaps, 10 or 15 percent."

He was not alone. In 2019, a group of 11,000 scientists signed a statement urging population control to slow human exploitation of Earth's fragile resources. With climate change, some have argued that limiting population growth - if not eugenics - could be part of saving the planet.

The famous geneticist Richard Dawkins in February 2020, sparked controversy when he tweeted that, aside from the moral problems, eugenics would work "in practice."

"It's one thing to deplore eugenics on ideological, political, moral grounds. It is quite another to conclude that it would not work in practice. Of course, it would. It works for cows, horses, pigs, dogs $\mathcal{E}$ roses. Why on earth wouldn't it work for humans? Facts ignore ideology."

It appears that the eugenics of today imposed by the New Leviathan, based on genetics, has the same aim as the old eugenics, the elimination of those considered inferior.

Though his glory is fading, the West is, scientifically, still superior to other civilizations. This is especially true of computer science, genetics and nanotechnology. In particular, the laboratory production and spreading of deadly viruses seems suitable for realizing the misunderstood Nietzsche's idea of a "new man", and for scaring the world's population to death through the pandemic.

In other words, the new viruses and new pandemics will follow relatively very soon. That is because the Covid 19 is just a beginning of the endless crises. The new Leviathan does not want to create viruses that will be too deadly. Every new pandemic they cause will kill "only" a few "undesirable" millions of people destroy a number of economies and, most importantly, completely paralyze the world population with fear and uncertainty. In this way, control over people, in addition to the one carried out with the help of video cameras, computers, satellites and mobile phones, becomes almost unlimited. A worldly god has replaced heavenly God.
It is to hope that the nonwestern powers will be able to produce the same viruses establishing, as with nuclear weapons, a balance of terror, thereby giving some chance to freedom.

Notes

/1/ There are two types of rationality. The first comes down to intelligent behavior within a situation that includes all elements of formal logic, in particular analysis and synthesis. It is often rational and to take a certain risk in order to solve something. Rational judgment must be freed from emotional bias and prejudice, and must handle the exact facts. Another kind of rationality is historical in nature. History has its own meaning and develops according to stages that are dialectical in nature and based on certain paradigms. When a historical paradigm is just established, it is rational to support it in every possible way. When the paradigm ceases to lose its veracity, it is rational to support what is new that is announced as the future paradigm of the progress of humanity on a higher level. Historical progress rests on significant figures who do not cause conservative attitudes of their environment and fulfill their mission with passion.

/2/ Islam is based on unconditional substantiation of God. After Judaism and Christianity, it represents the third monotheistic religion. The most important file on which it is based is Koran, a term from Arabic, which denotes recitation. In this sense, it is considered the word of God. For Islam, there is only one God, and there is no trinity. Mohammed, is his prophet, and he is a man. There are no worshipes in it, such as Jesus Christ. God exists for eternal times, he should be subdued, and without opposition. Just as in the New Testament, a terrible judgment will reward the good and punish the bad.

13/ The Silk Road was and is a network of trade routes connecting the East and West, and was central to the economic, cultural, political, and religious interactions between these regions from the 2 nd century BCE to the 18th century. In the present day, trade takes place on the Silk Road on land and on the maritime branch. There are several projects under the name of "New Silk Road" to expand the transport infrastructure in the area of the historic trade routes. The best known is probably the Chinese Belt and Road Initiative (BRI).

/4/ It is known that for Hegel "the Cunning of Reason" means the process by which worldly particulars (Cesar, Napoleon..) are used by universal Reason for its own purposes. 
/5/ The most drastic example of this is Romania. She had paid off the entire imf debt and had torn herself out of debt bondage. This, of course, was intolerable and should have punished the Romanian government led by Ceausescu. While he was out of his country, the opposition, along with intelligence Western services, dug up thousands of dead people, painted them red, as if it were blood, lined them together and filmed it! The images went around the world, and the explanation was that this was the latest crime of the Ceausescu regime! The revolting people rose to the uprising, toppled power and shot Causesc. (En décembre 1989, à la veille du réveillon de Noël, alors qu'en Roumanie tombait la dictature de Nicolae Ceausescu, les téléspectateurs occidentaux découvraient avec horreur les images d'un charnier où, affirmaient les envoyés spéciaux, gisaient des corps affreusement torturés. On parlait alors de quatre mille morts pour la seule ville de Timisoara. L'émotion soulevée était immense ; les éditoriaux solennels et les appels à l'action se multipliaient. En fin de compte, il s'avéra que les cadavres exhibés devant les caméras avaient été déterrés dans le cimetière des pauvres) Le Monde Diplomatique, Il y a vingt ans le faux charnier de Timisoara, 21 Decembre, 2009.

/6/ For exemple, Cold War era games included Conflict: Middle East Political Simulator created by Virgin Interactive, Spectrum Holobyte's Crisis in the $\underline{\text { Kremlin }}$ and virtually unknown Hidden Agenda. Conflict simulated a hypothetical situation in 1997 in which the player assumes the role of the Israeli Prime Minister and is obligated to employ various diplomatic and covert directives to defeat its rival nations. Surrounded by hostile nations, the player is restrained by a very limited military force and thereby encouraged to employ peaceful means to remain in power until he acquired more advanced weapons systems and power.

In Crisis in the Kremlin, the user could play as the protege of any of the following Soviet politicians: Mikhail Gorbachev of the reformist faction; Yegor Ligachev, leader of the hardline faction; and Boris Yeltsin, who was the prevalent figure of the nationalist faction. The player could use the simulation to test certain strategies to lead the failing Soviet Union into a new era of prosperity or force its dissolution and integration into the new world order.

(https://en.wikipedia.org > wiki)

/7 /Heraclitus speaks of the unity of all beings, who are in constant change. The world is full of opposites, and everything is in motion: there is no immutable battle. Everything flows, is a formula that sums up his teachings, which are eminently dialectical. Everything moves, everything is constantly changing; things are created, changed and decayed. Reality, created by the struggle of opposites, is in the eternal process of becoming. We only know things by their opposites. https://hr.wikipedia.org > wiki > Hera.

/8/ Hegel, G. W. F., La phenomenologie de l'esprit, Paris, Aubier, 1991, p. 154

19/ What applies to the dialectical development of society also applies to the development of the lessons. Thus, for example, the classical geometry by which space is flat, had to be complemented by a new geometry by which space is curved. Or, Newton classic mechanics, it's complemented by relativity theory. Of course, Euclid's geometry and Newton mechanics are still in daily use, but they are unable to explain what is happening in space and subatomic spaces.

/10/ Hegel's thesis is that without a state there is no historical people. "Philosophical consideration is appropriate and worthy for history to begin where mindfulness begins to enter into secular existence," i.e., to begin. where freedom is irradiated in the state of a nation so that law and law as substantive objects of custom apply as the basis of freedom of self-awareness, which has risen above "assiduousness into nature".

(Ante Pazanin, Povijesni $i$ "nepovijesni" narodi, Politička misao, vol. XXXI, 1994.)

/11/ Marx/Engels, Manifesto of the Communist Party (Bourgeois and Proletarians)

/12/ Dumont R., Un monde intolerable, Paris, Editions de Seuil, 1988, p. 214

/13/ Yet Brando, ever the anarchist at heart, decided he would not attend. In fact, on the eve of the awards he announced that he would boycott the 45th annual Academy Awards and instead would send a representative to take his place should he win. He would send a little-known actress and the President of the National Native American Affirmative Image Committee, Sacheen Littlefeather. It was a bold move intended to make a statement.

When Roger Moore and Liv Ullman announced Brando's name as the winner of the Best Actor award, Littlefeather arose from her seat in full Apache dress and solemnly made her way to the stage with intent. As Moore began to put the award under her nose, Littlefeather motioned it away with an open palm; she stood behind the podium, looked at the crowd, set down a 15-page letter Brando had passed along beside her and begun. 
She said, "I'm representing Marlon Brando this evening, and he has asked me to tell you that he very regretfully cannot accept this very generous award. And the reasons for this being are the treatment of American Indians today by the film industry." At this point, the crowd began to boo and were clearly enraged both by the refusal and the gall to accuse the industry at their own celebration.

https://faroutmagazine.co.uk, marlon-brando-rejected-.

/14/ Elisabeth Lévy : «Le multiculturalisme bisounours est mort» Par Alexandre Devecchio

Published in Figaro on 05/02/2016 at 19:02, Updated on $05 / 02 / 2016$ at 19:14

Elisabeth Lévy is a journalist and managing editor of Causeur. In its February issue, entitled ,'Migrants and Women, the Cologne Syndrome', the magazine questions the limits of the multicultural model.

The latest issue of Causeur is entitled "Migrants and Women, the Cologne syndrome." According to you, the night of Cologne would not have this explosive symbolic charge if the sexual dimension were not coupled with a cultural dimension

It is there, it is taking place in our cities, before our eyes and the sorcerer's apprentices of multiculturalism persist, not only in not seeing, but in invective and disqualifying all those who see, gathered in ridiculous blacklists that do not even sell paper anymore....

And what is there to see that we do not see?

... Men of Arab-Muslim culture had attacked Western women, and in this case the origin of the perpetrators and victims had played a role in the crime. In addition, on this occasion, a corner of the veil has risen and we learn that, throughout Europe, similar events are taking place quietly, in a less spectacular way, more isolated than in Cologne....They are trying to sell us a happy multiculturalism in which all cultures join hands and where another gentillet tells us "to you the miniskirt, to me the burqa, live with our differences inch'Allah". ;

One consequence has been a change in the position of women in Europe. Many Muslim migrants don't feel or express contempt for women. But some do-enough to drive a trend.

One shocking event that drew attention to this trend was the wave of sexual assaults on New Year's Eve 2015-2916 in Germany. According to German police, more than 1200 women werw assaulted of whom 24 said they were raped. The perpe- trators often acted in gangs attacking lone women. (WSJ OPINION, By Ayaan Hirsi Ali, Feb. 22, 2021 1:07 pm ET)

/15/ In New York City, it's illegal to discriminate on the basis of gender identity and gender expression in the workplace, in public spaces, and in housing. The NYC Commission on Human Rights is committed to ensuring that transgender and gender non-conforming New Yorkers are treated with dignity and respect and without threat of discrimination or harassment.

TIPES of BISEXUALITY

BI-GENDERED • CROSS-DRESSER • DRAG KING • DRAG QUEEN FEMME QUEEN • FEMALE-TO-MALE • FTM • GENDER BENDER GENDERQUEER • MALE-TO-FEMALE • MTF - NON-OP • HIJRA PANGENDER • TRANSEXUAL/TRANSSEXUAL • TRANS PERSON WOMAN • MAN • BUTCH • TWO-SPIRIT • TRANS • AGENDER THIRD SEX • GENDER FLUID - NON-BINARY TRANSGENDER ANDROGYNE • GENDER GIFTED • GENDER BLENDER • FEMME PERSON OF TRANSGENDER EXPERIENCE • ANDROGYNOUS

/16/ Same-sex marriage in California - Wikipedia https://en.wikipedia.org > wiki > Sa..

/17/ New York Times: Spike the food supply with sterilization chemicals to cause global infertility and depopulation Thursday, September 14, 2017 by: Mike Adams Tags: depopulation, eugenics, history, Inferti-

lity, New York Times, population control, science, sterilization

(Natural News) A November 4, 1969 New York Times feature article authored by Gladwin Hill called for sterilization chemicals to be added to the food supply in order to achieve globalist goals of human depopulation. That article, entitled "A Sterility Drug in Food is Hinted" came with the byline, "Biologist Stresses Need to Curb Population Growth."

Most people living today - especially younger people - have no idea that a key agenda of globalism is the elimination of "undesirable" humans from the gene pool. They believe that ideas of "eugenics" and genocide were only carried out by the Nazis, not by American university professors and presidential science advisors. So they have no grasp of the context in which Planned Parenthood, for example, operates today as a depopulation engine to eliminate blacks from society. (Planned Parenthood's founder, Margaret Sanger, was a black-hating eugenicist whose ideas directly inspired the genocidal goals of the Third Reich.)

The New York Times article quotes Dr. Paul Ehrlich of Stanford University, a depopulation advo- 
cate, as well as President Richard Nixon's chief science adviser, Dr. Lee DuBridge, who said that "population control should be the prime task of every government.";

Covert vectors for depopulation that are being pursued right now

The depopulation goals from 1969 are in full force in America today. Some of the vectors for covert sterilization and depopulation now include:

Covert genetic modification of crops to grow RNA interference fragments that nullify male fertility in humans.

The continued use of toxic mercury in flu shots in order to cause spontaneous abortions in pregnant women.

Planned Parenthood abortion centers that target minority communities for eugenics "cleansing" of the gene pool.

Inoculation of all vaccine recipients with hidden, cancer-causing viruses that are deliberately allowed to contaminate many vaccines. (See the SV40 Simian Virus fiasco affecting 98 million Americans via the polio vaccine.) (Also, read the book "Plague" by Judy Mikovitz.)

The planned, deliberate use of cancer-causing ingredients in the popular food supply, including sodium nitrite in processed meat, inducing widespread cancer and early deaths (the clueless population then eats itself to death, while enriching the cancer industry).

Spiking public health vaccines with covert sterilization chemicals, exactly as has been confirmed in African vaccination campaigns that target young black women for sterilization without their knowledge or consent.

(Source: The New York Times, Published: November 25, 1969)

/18/ Carl Schmitt (1888-1985) was a conservative German legal, constitutional, and political theorist. Schmitt is often considered to be one of the most important critics of liberalism, parliamentary democracy, and liberal cosmopolitanism. But the value and significance of Schmitt's work is subject to controversy, mainly due to his intellectual support for and active involvement with National Socialism.We will follow his ideas expressing in the article The Concept of the Political" published in 1996, by The University Chicagog Press.

/19/ A deep state (calque of Turkish: derin devlet is a type of governance made up of potentially secret and unauthorised networks of power operating independently of a state's political leadership in pursuit of their own agenda and goals. In popular usage, the term carries overwhelmingly negative connotations. The range of possible uses of the term is similar to that for shadow government. The expression state within a state is an older and similar concept. Historically, it designated a well-defined organization which seeks to function independently, whereas the deep state refers more to a hidden organization seeking to manipulate the public state.

Potential sources for deep state organization include rogue elements among organs of state, such as the armed forces or public authorities such as (intelligence agencies, police, secret police, administrative agencies, and government bureaucracy). "Deep state" rhetoric has in recent years been used in the United States to describe what in many cases may be the work of entrenched career bureaucrats or civil servants acting in accordance with the mandate of their agency and congressional statutes, when seen as in conflict with the current presidential administration.

The intent of a deep state can include continuity of the state itself, job security, enhanced power and authority, and the pursuit of ideological or programmatic objectives. It can operate in opposition to the agenda of elected officials, by obstructing, resisting, and subverting their policies, conditions and directives. Conspiracy theories of a secret government typically go far beyond these verifiable agencies and posit actions by more obscure bodies. (Wikipedia)

/20/ The global deep state: A new world order brought to you by COVID-19 Published Wednesday, Apr. 28, 2021, 12:00 am

By John W. Whitehead \& Nisha Whitehead

For good or bad, COVID-19 has changed the way we navigate the world.

It is also redrawing the boundaries of our world (and our freedoms) and altering the playing field faster than we can keep up.

Owing in large part to the U.S. government's deep-seated and, in many cases, top-secret alliances with foreign nations and global corporations, it has become increasingly obvious that we have entered into a new world order-a global world order-made up of international government agencies and corporations.

This powerful international cabal, let's call it the Global Deep State, is just as real as the corporatized, militarized, industrialized American Deep 
State, and it poses just as great a threat to our rights as individuals under the U.S. Constitution, if not greater.

We've been inching closer to this global world order for the past several decades, but COVID-19, which has seen governmental and corporate interests become even more closely intertwined, has shifted this transformation into high gear.

Fascism has become a global menace.

/21/ In May 2020, when the coronavirus caused global panic and blockade away from the initial outbreak in Wuhan, British Crown Prince Charles, along with WEF founder Klaus Schwab, discovered what they gleefully called the Great Reset. World political and business leaders are increasingly using terms such as the big reset or the fourth industrial revolution and calling for "build better," which the Biden administration also prefers.

The most striking fact about the Great Reset program is that the same giga-rich plutocratic families responsible for the shortcomings of the current world economic model enhance it. They, not us, created the demise of organic fields and nature with their Roundup Glyphosate and toxic pesticides. They have been spoiling the air quality in our cities with the transportation models they impose on us. Now, while we are being blamed for alleged catastrophic $\mathrm{CO} 2$ emissions, we are conditioned to accept guilt and be punished so that Greta and her friends "save the next generation".

Behind the seductive rhetoric of power that will be on creating a "sustainable" world lies a program of raw eugenics, depopulation on a scale they have never tried before. It is not a man; in fact, some call him "transhuman." In 2016, WEF chief Schwab wrote a book called Shaping the Future of the Fourth Industrial Revolution. In it, he describes the technological changes that come with the fourth industrial revolution of $5 \mathrm{G}$ smartphones, the Internet, artificial intelligence that connect everything to everything to make the most banal decisions for us, such as buying more milk or working stoves. At the same time, data is centralized in private corporations such as Google or Facebook so that tech giants can monitor our every breath.

Schwab describes how next-generation technologies - already introduced by Google, Huawei, Facebook and others - will allow governments to "enter the private space of our minds so far, reading our minds and influencing our behavior." "The technologies of the fourth industrial revolution will not stop you from becoming part of the physical world around us - they will become part of us," Schwab said. "Today's external devices from wearable computers to virtual reality headsets - will almost certainly become implantable into our bodies and brains".

Schwab also adds, "What the fourth industrial revolution will lead to is a blend of our physical, digital and biological identity." Among these fusion technologies are "active implantable microchips that break through the skin barrier of our body," Schwab explained. These "implantation devices are also likely to help communicate thoughts that are usually expressed verbally, through a built-in smartphone and potentially unexplored thoughts or moods by reading brain waves and other signals."

Portal BETA.BA, 27. o1. 2021.

/22/ Advanced industrial robotics, self-driving cars and trucks, and intelligent cancer-screening machines presage a world of ease, but they also make us uneasy. After all, what would human beings do in a largely automated future? Would we be able to adapt our institutions to realize the dream of human freedom that a new age of intelligent machines might make possible? Or would that dream turn out to be a nightmare?

The resurgence of automation discourse today responds to a real, global trend: there are too few jobs for too many people. Chronic labor underdemand manifests itself in economic developments such as jobless recoveries, stagnant wages, and rampant job insecurity. It is also visible in the political phenomena that rising inequality catalyzes: populism, plutocracy, and the emergence of a sea-steading digital elite-more focused on escaping in rockets to Mars than on improving the lives of the digital peasantry who will be left behind on a burning planet.

DISSENT, Aaron Benanav, A World Without Work, Fall 2020

/23/ Early treatment of COVID-19 patients with hydroxychloroquine ...

https://www.ncbi.nlm.nih.gov , articles, PMC7199729 by M Million · 2020 .

124/ The Guardian“The Lancet has made one of the biggest retractions in modern history. How could this happen? James Heathers, Jun 5, 2020)

/25/ DESERT REVIEW Thousands of medical professionals declare COVID policies "Crimes Against Humanity", Sep 28, 2021

/26/ Philippe Aimar, Enquete sur un virus, Le jardin des livres, Paris, 2021.

An investigation into the origins of the coronavirus pandemic. The author claims that this is a bi- 
ological, political and media manipulation, orchestrated in particular by the Bill Gates Foundation. He assures that the first cases appeared as early as October 2019 and that the simulation of a global pandemic, organized on October 18, 2019 in New York, aimed to prepare for the health crisis.

/27/ Vineet D Menachery, Boyd L Yount Jr, Kari Debbink, Sudhakar Agnihothram, Lisa E Gralinski, Jessica A Plante, Rachel L Graham,

Trevor Scobey, Xing-Yi Ge, Eric F Donaldson, Scott H Randell,

Antonio Lanzavecchia, Wayne A Marasco, Zhengli-Li Shi \&

Ralph S Baric

Published: 09 November 2015

Nature Medicine, volume 21, pages15081513(2015)

30 March 2020 Editors' note, March 2020: We are aware that this article is being used as the basis for unverified theories that the novel coronavirus causing COVID-19 was engineered. There is no evidence that this is true; scientists believe that an animal is the most likely source of the coronavirus.

/28/ In 2011, Fouchier and Kawaoka alarmed the world by revealing they had separately modified the deadly avian H5N1 influenza virus so that it spread between ferrets. Advocates of such gain of function (GOF) studies say they can help public health experts better understand how viruses might spread and plan for pandemics. But by enabling the bird virus to more easily spread among mammals, the experiments also raised fears that the pathogen could jump to humans. And critics of the work worried that such a souped-up virus could spark a pandemic if it escaped from a lab or was intentionally released by a bioterrorist. After extensive discussion about whether the two studies should even be published (they ultimately were) and a voluntary moratorium by the two labs, the experiments resumed in 2013 under new U.S. oversight rules. (EXCLUSIVE: Controversial experiments that could make bird flu more risky poised to resume

By Jocelyn KaiserFeb. 8, 2019 , 8:45 PM)

/29/ David Alton Citizens need to be more alert to the danger of totalitarianism https://www.gisreportsonline.com >

/30/ As of Jan. 5, Black death rates and Hispanic death rates from COVID-19 were 2.3-2.5 times those of white people, according to the CDC. Indigenous death rates were 2.2 times those of white people. (BY NOAH BERLATSKY, JANUARY 19, 2021, 3:05 PM, FP)
/31/ Idem

/32/ For the first quarter of year, 2020, a 5.4\% drop in working hours worldwide was calculated, which is 155 million jobs less than the fourth quarter of last year. Their 'saviors' will once again be the same ones who rule the world economy, which is otherwise called neocolonialism. Finally, the corona-feared population 'to the bone' lost, fearing disease, every critical consciousness and allowed authoritarianism, in various forms, to take over their $l i-$ ves. The most ordained of all is the fact that this tragic situation has benefited the richest. So, for example, according to the media, the wealth of American billionaires increased by more than $10 \%$ in just three weeks of the corona crisis. Namely, of the 400 richest people on Forbs' list, at least eight billionaires have earned, since the pandemic began, $\$ 1$ billion each. Only a few of them with higher earnings are the founders of Zoom, owners of Microsoft, Skype, and Microsoft Teams. Yet none of them profited as much as the founder of Amazon - Jeff Bezos made $\$ 25$ billion as of January 1, 2020 (ttps://www.forbes.com $>$ forbes$\underline{400)}$

/33/ It is since last January, with the introduction in Italy of the state of emergency by the government of Giuseppe Conte, that I feel myself at war, literally catapulted night and day into a trench. I feel at war certainly not against a "virus" or an invisible enemy, but against a government that is totally heterodirected by very dangerous forces and powers that have staged a real global coup aimed at the progressive reduction and cancellation of democracy, freedom and civil rights, the repression of any dissent and the establishment of a world-wide Orwellian technocratic-health dictatorship. This plan, which has been going on undisturbed for many years and which unfortunately also sets itself other even more dangerous objectives, has directly involved most of the world's governments and some Europeans in particular... All European governments already knew from September 2019 what would happen and have received enormous clandestine funding (not officially declared), a real rain of money, certainly not to finance and strengthen health care and hospitals, but exclusively to declare the lockdown and to ensure its sealing through the massive strengthening of the Police. ESCLUSIVO, Il Giornalista Nicola Bizzi: "Sapevano Del Coronavirus Dallo Scorso Autunno, Il Presidente Serbo Vučić Ha Preso I Soldi" By Davide Donateo Last updated Set 7, 2020 
/34/ Those vaccinated with Russian and Chinese vaccines cannot get a "COVID passport", nor travel to Western countries.

/35/ "While the precise origin of SARS-CoV-2, the virus that causes COVID-19, remains unknown, several fact-checkers and media outlets found themselves in an embarrassing position when a theory they had previously dismissed as 'baseless' gained new attention from scientists," Hirschauer and Lasch argued. "That theory holds that the novel coronavirus did not originate from human contact with an infected animal, but instead was leaked - intentionally or otherwise from the Wuhan Institute of Virology." For months before elite opinion on the subject began to turn, fact-checkers, media figures, and social-media platforms dismissed the lab-leak theory out of hand while relying on questionable evidence," they continue, identifying PolitiFact as one of the biggest culprits. In September 2020, PolitiFact and FactCheck.org published fact checks of claims made by Chinese virologist Li-Meng Yan that COVID-19 was "a man-made virus created in the lab." PolitiFact's Daniel Funke dismissed it as a "debunked conspiracy theory" and slapped a "Pants on Fire!" rating on Yan's statement. FactCheck.org's Angelo Fichera agreed it was an "unsubstantiated claim." Following new reporting, both outlets were forced to add editors' notes in May acknowledging the lab leak theory is a possibility. PolitiFact would go on to archive its original fact check on the subject." (Media, Published June 3, By Cortney O'Brien, Fox News)

/36/ Report shows scientists from China, US planned to create new coronaviruses in 2018 By Ifeanyi Ibeh, with agency reports 06 October 2021 | 1:33 pm

Scientists from the Chinese city of Wuhan and the United States planned to mix the genetic codes of other viruses to create novel coronaviruses that did not exist in nature, proposals show.

According to UK newspaper, The Telegraph, documents of a grant application submitted to the US Defense Advanced Research Projects Agency (DARPA), leaked in September, reveal that the international team of scientists planned to blend genetic data of closely related strains and grow completely new viruses.

The proposal was submitted on behalf of the Daszak EcoHealth Alliance, the Wuhan Institute of Virology, the University of North Carolina, and Duke NUS in Singapore by the British zoologist Peter Daszak. Daszak, currently a member of the World Health Organization
(WHO) team investigating the pandemic's origins, was also behind a letter published in The Lancet which dismissed suggestions that Covid did not have a natural origin as a conspiracy theory. The plans made in the DARPA documents included inserting a section into existing viruses to make them more infectious to humans and inoculating wild bats with aerosolised engineered spike proteins from viruses. According to The Telegraph, a genetics expert with the WHO, who discovered the plan after studying the proposals in depth, said that if Sars-CoV-2 was created in this way, it would explain why a close match has never been found in nature. Banal-52, which was discovered in Laos last month and shares 96.8 per cent of the genome with Sars-CoV-2, is the closest naturally occurring virus so far. However, scientists expect a direct ancestor to be a 99.98 per cent match - and none has yet been discovered. The DARPA proposals, which were leaked to the DRASTIC pandemic origins analysis group, show that the team intended to use sequences from naturally occurring coronaviruses to create a new sequence that was an average of all the strains. The grant application, submitted in 2018, according to The Telegraph, states: “We will compile sequence/RNAseq data from a panel of closely related strains and compare full length genomes, scanning for unique SNPs representing sequencing errors. "Consensus candidate genomes will be synthesised commercially using established techniques and genome-length RNA and electroporation to recover recombinant viruses." A WHO collaborator, who did not want to be identified for fear of retaliation, explained the proposal as follows: "This means that they would take various sequences from similar coronaviruses and create a new sequence that is essentially the average of them. It would be a new virus sequence, not a 100 per cent match to anything. "They would then synthesise the viral genome from the computer sequence, thus creating a virus genome that did not exist in nature but looks natural as it is the average of natural viruses. "Then they put that RNA in a cell and recover the virus from it. This creates a virus that has never existed in nature, with a new 'backbone' that didn't exist in nature but is very, very similar as it's the average of natural backbones." According to the report, the source said it was noteworthy that the cut-off for generating such an average sequence was viruses that only had five per cent genetic divergence from each 
other. Scientists at the Wuhan Institute of Virology announced in 2020 that they discovered RaTG13, a 96.1 per cent match to Sars-CoV-2, in bat droppings in a cave in Yunnan province in 2013. RaTG13 may have been included in a collection of viral genomes to aid in the creation of an average sequence. Despite the fact that the grant proposal was turned down in 2018, the Wuhan database of viral strains was taken offline 18 months before the Covid outbreak, making it impossible to determine which viruses the team was working on or had created.

/37/ "Uttar Pradesh was the first state in the country to introduce large-scale prophylactic and therapeutic use of Ivermectin. In May-June 2020, a team at Agra led by Dr. Anshul Pareek, administered Ivermectin to all RRT team members in the district on an experimental basis. It was observed that NONE OF THEM developed COVID-19 despite being in daily contact with patients who had tested positive for the virus," Uttar Pradesh State Surveillance Officer Vikssendu Agrawal said. https://indianexpress.com/article/cities/lucknow/uttar-pradesh-government-says-ivermectin-helped-tokeep-deaths-low-7311786/; in India. The new guideline includes Ivermectin for early treatment - to treat patients with mild symptoms. The New York Times COVID "Mystery" solved! Cases have plunged in India in a few weeks. True The New York Times reported on July 30,2021, that this is a mystery with no clear explanation. But, the drop in cases happened right after a new COVID-19 protocol was released_On September 22, 2021, YouTube hosted a video by popular science blogger Dr. John Campbell detailing the Uttar Pradesh success story. He gave a breakdown of the ingredients and dosages of the magical medicine home treatment kit responsible for eradicating COVID in Uttar Pradesh. The same kit was also used in the state of Goa. Dr. John Campbell broke India's Ivermectin Blackout wide open on YouTube by revealing the formula of the secret sauce, much to the dismay of Big Pharma, the $\mathrm{WHO}$, and the CDC. Readers will want to watch this before it is taken down. See mark 2:22. https://youtu.be/eO9cjy3Rydc

Each home kit contained the following: Paracetamol tablets [tylenol], Vitamin C, Multivitamin, Zinc, Vitamin D3, Ivermectin $12 \mathrm{mg}$ [quantity \#10 tablets], Doxycycline $100 \mathrm{mg}$ [quantity \#10 tablets]. Other non-medication components included face masks, sanitizer, gloves and alcohol wipes, a digital thermometer, and a pulse oximeter. See mark 2:33. Campbell reports that the exciting things in the kit that grabbed his attention were: Zinc, Vitamin D3, Ivermectin, and secondary antibiotic treatment. "Interesting, that's what the government decided to give." India's Ivermectin Blackout - Part V: The Secret Revealed https://www.thedesertreview.com > ...

· 27. ruj 2021. - On August 6, 2021, India's Ivermectin media blackout ended with MSN reporting. Western media, including MSN, finally acknowledged what was ...

/38/ Vaccine monopolies increasing cost of vaccinating the world against Covid

Posted by: Caroline Reid

In a briefing note, the Global People's Vaccine Alliance highlighted examples of how much both developing and wealthier nations have been potentially overpaying for Covid-19 vaccines. The analysis found that:

- $\quad$ The EU may have overpaid for their 1.96 billion Moderna and Pfizer/BioNTech vaccines by as much as $€ 31$ billion

- $\quad$ Pfizer/ BioNTech are charging their lowest reported price of $\$ 6.75$ to the African Union - nearly six times more than the estimated potential production cost of this vaccine

- Colombia, which has been badly affected by Covid, has been paying double the price paid by the US for Moderna vaccines

The cost of vaccinating the world against Covid-19 could be at least five times cheaper if pharmaceutical companies weren't profiteering from their monopolies on vaccines, campaigners from the Global People's Vaccine Alliance campaign said today.

New analysis by the Alliance shows that the firms Pfizer/BioNTech and Moderna are charging governments as much as $\$ 41$ billion above the estimated cost of production. The EU, for example, has potentially overpaid by as much as $€ 31$ billion for its 1.96 billion doses of the Pfizer/BioNTech and Moderna vaccines, in comparison to the estimated cost price.

Jim Clarken, Chief Executive of Oxfam Ireland said: "Despite a rapid rise in Covid cases and deaths across the developing world, Pfizer/BioNTech and Moderna have sold over 90 percent of their vaccines so far to rich countries, charging up to 24 times the potential cost of production. 


\title{
KRAJ POVIJESTI, COVID 19 I NOVI LEVIJATAN PREKINUTA KOMUNIKACIJA IZMEĐU MODERNIZMA I POSTMO- DERNIZMA
}

\author{
Emil Vlajki \\ Fakultet političkih znanosti, Sveučilište u Banja Luci, Bosna i Hercegovina
}

\section{Sažetak}

Ovo djelo govori o duhu zapadne civilizacije i njezinim iskušenjima. Oslanjajući se na Hegelovu filozofiju povijesti, tekst objašnjava zašto je donedavno ova civilizacija bila dominantna nad ostatkom svijeta. Stvar je u tome što je razumjela važnost racionalnosti, podredila sve manifestacije života njoj, a posebno, tijekom kapitalizma (modernizma), razvila znanost i tehnologiju i proizvela moćno oružje. Usput je u svoj sustav racionalnosti uključila sva značajna dostignuća drugih civilizacija i naroda. U tom smislu, Hegel u uvodu filozofije povijesti kaže: "Jedina misao koju filozofija donosi sa sobom u kontemplaciju povijesti je jednostavna koncepcija Uma; da je Um vladar svijeta; da nam povijest svijeta, dakle, predstavlja racionalan proces." Drugim riječima, povijest je isključivo okupirana pokazivanjem kako Um dolazi do priznanja i usvajanja Istine. Naravno, racionalnost je nešto što pripada svim civilizacijama i narodima, ali su druga društva, iz različitih razloga (geografskih, klimatskih, vjerskih itd.) podredila racionalnost nekim drugim imperativima. Stoga mnoge od tih zajednica nisu bile povijesne. Što god da je bilo, Zapad je iskoristio svoju nadmoć kolonizirajući druge civilizacije i uništavajući neke. Sa uobičajenog moralnog stajališta, to je neprihvatljivo, kriminalno. Međutim, Hegelova filozofija, donekle u Marxovoj i Engelsovoj interpretaciji, govori nešto drugo. Povijest ima svoj smisao. Njegov primarni cilj je sačuvati čovječanstvo od svega što bi ga moglo uništiti, osobito od raznih prirodnih kataklizmi i smrtonosnih bolesti. Smisao povijesti je i njegov napredak prema civilnom društvu kao ostvarenju slobode i kraja povijesti. To je bilo moguće samo usvajanjem i prakticiranjem apsolutne racionalnosti. Zašto oružje i nasilje? Apsolutna racionalnost, da bi bila povijesno učinkovita, morala je pokriti cijeli svijet. Na Zapadu je, kao "izabrana civilizacija", to trebalo ostvariti, a on je, vojno superioran, to učinio koristeći nad drugim civilizacijama i narodima ekstremno nasilje. $S$ druge strane, ovom nemilosrdnom eksploatacijom koloniziranih područja, Zapad se mogao brzo razvijati u svim domenima i tako, na razini mogućnosti, omogućiti najbolju sudbinu čovječanstva. Posebno je važno bilo XX stoljeće. Tada je ova civilizacija, razvijajući medicinu, genetiku, informatiku, nanotehnologiju i robotiku, uspjela pobijediti razne smrtonosne bolesti, započeti istraživanje svemira i pretvoriti pustinje u plodna tla i, uz "zelenu revoluciju", proizvoditi hranu za sve stanovnike planeta. Vidjevši prednosti racionalnosti, druga područja svijeta, s različitim uspjehom, slijedila su primjer Zapada. Kolonijalizam je nestao, a ljudska prava i međunarodni odnosi bili su institucionalizirani, osobito u deklaracijama Ujedinjenih naroda. Uspostavljen je detant između dva bloka, kapitalizma i socijalizma, a pokret nesvrstanih pridonio je stabilizaciji svijeta. Što se tiče svjetskih ekoloških problema koji proizlaze iz često nekontrolirane industrijaliza- 
cije, i oni, iako mučno i sporo, nastoje biti riješeni na globalnoj razini. Za razliku od modernizma, koji je konstituiran kao moderno civilno društvo s usvojenim načelom jednakosti svih, sadašnji postmodernizam je suprotan svemu građanskom. Tržišna ekonomija sve lošije funkcionira, napuštene su velike utopijske ideje: kršćanstvo i marksizam, "nova ljudska prava" uništila su sve plemenito od već proglašenih univerzalnih ljudskih prava. U nastalom beznadnom kaosu, zabrinute zbog uspona Kine i Rusije, najvažnije snage na Zapadu prešle su u "ilegalu", stvaranjem globalne duboke države, Novog Levijatana. Djeluje, prema potrebi, putem formalnih i neformalnih mehanizama. Ako je potrebno, on se također protivi vlastima svojih država ako smatra da njihovi postupci urušavaju ovu civilizaciju. Kao dobar učenik Carla Schmitta, njemačkog političkog filozofa, on je protiv humanizacije međuljudskih odnosa; ima ogromna financijska i tehnička sredstva i neljudske, eugeničke ideje o smanjenju svjetske populacije. Više nema sumnje da njegove metode uključuju proizvodnju i širenje smrtonosnih virusa. Ciljevi djelovanja tih antiliberalnih svjetskih vlasti u sjeni, je uništenje cijelog postojećeg humanizma i nema nikakve veze s poviješću ili bilo kakvim smislom.

Primjedba. Levijatan je morsko čudovište spomenuto u biblijskoj Knjizi o Jobu, gdje je povezan sa silama kaosa i zla. Metaforički, Levijatan je ogroman i moćan društveni organizam koji živi skriven u dubokoj tami, izvan bilo kakve pravne društvene kontrole. Rad ima dva dijela:

- Smisao povijesti, modernizam i nužnost zapadnog nasilja

- Postmodernizam, sumrak Zapada i Novi Levijatan

Slijedi zaključak o budućnosti čovječanstva.

\section{Ključne riječi}

Hegel, povijest, dijalektika, racionalnost, komunikacija, modernizam i postmodernizam, Zapad, zapadno nasilje, civilno društvo, globalna duboka država, kapitalizam, Carl Schmitt, eugenika, Kovid 19, vakcina, ekstremna svjetska desnica, međunarodni odnosi, patologija uma, novi svjetski poredak, "veliko resetiranje".

Respecting the reviewers' opinions, the Editorial Board distances itself from the views, information and sources cited in the text.

Uvažavajući recenzentska mišljenja, Uredništvo se ograđuje od stavova, informacija i izvora navedenih $u$ tekstu 